\title{
THE EFFECTS OF DIETARY CATION-ANION BALANCE \\ ON ACID BASE BALANCE AND BLOOD \\ PARAMETERS IN ANAEROBICALLY \\ EXERCISED HORSES
}

\author{
By \\ JOSEPH CHARLES POPPLEWELL \\ Bachelor of Science \\ Oklahoma state University \\ Stillwater, Oklahoma
}

1988

\author{
Submitted to the Faculty of the \\ Graduate college of the \\ Oklahoma State University \\ in partial fulfillment of \\ the requirements for \\ the degree of \\ MASTER OF SCIENCE \\ December, 1993
}


THE EFFECTS OF DIETARY CATION-ANION BALANCE

ON ACID-BASE BALANCE AND BLOOD

PARAMETERS IN ANAEROBICALLY

EXERCISED HORSES

Thesis Approved:

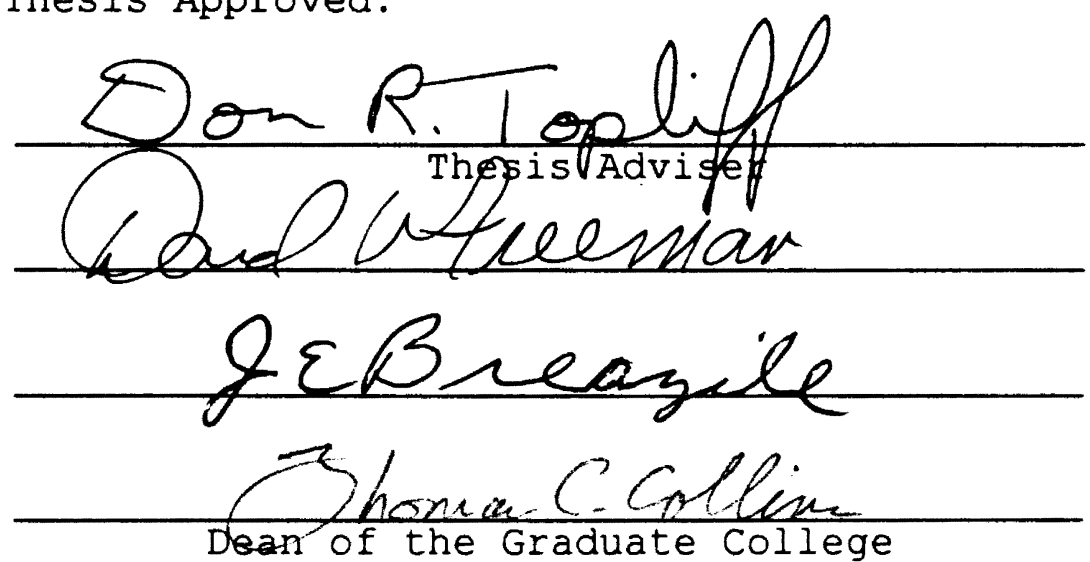


ACKNOWLEDGEMENTS

I would like to thank my major adviser Dr. Don Topliff and Dr. David Freeman for their support, understanding, and guidance during my research project. I would also like to express my appreciation to $\mathrm{Dr}$. James Breazile for serving on my committee and more importantly, for his informative physiology lectures. I would also like to extend thanks to Dr. Bill Tucker and Dr. Robert Wetteman for the use of their lab space and equipment during this project.

Without the help of Jackie Cherry, Laruth Mackay, FeFe Melouk, and Donna Perry, my lab work would have not gone as smoothly as it did. These ladies provided much experience and expertise as well as the use of their equipment throughout my trials. Many thanks to all of you.

A special thanks goes to Stacy Lee, Equine Center Manager, for his patience and understanding during this trial. Thank you stacy for your advice and your help.

I would like to extend my thanks to the following students; Judy Barngrover, Leigh Ann Higgins, Amanda Simmons, and especially to my right hand (and sometimes my left), Bryant Craig. Without your tireless efforts and patience, this research project could not have been 
accomplished. To my friends and fellow graduate students; Lance Baker, Trigg Rentfro, Ward Stutz and Dan Wall, I can't thank you guys enough for your help and advice.

Without the love and support from my father and mother, Charles and Adel Popplewell, my father and mother-in-law, Karl and Ann Geppert, and all of my brothers and sisters, I would have never had the strength and courage to complete this degree. I can never repay the dedication, encouragement and prayers they have given me.

The dedication of this thesis goes to my inspiration, my optimism and my perseverance, which are synonymous with my wife, Susie. I hope this work will make a positive difference in your life and the lives of our wonderful daughters, Emily and Karly. 
TABLE OF CONTENTS

Chapter

Page

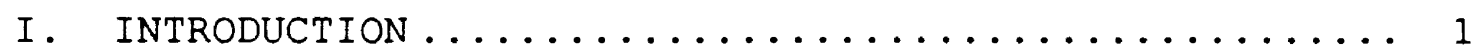

II. LITERATURE REVIEW .................... 3

Overview of $\mathrm{DCAB} \ldots \ldots \ldots \ldots \ldots \ldots \ldots \ldots \ldots \ldots \ldots \ldots$

DCAB Research in other species ............. 4

Rabbit ..................... 4

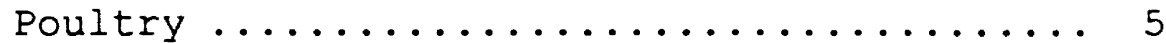

Swine ....................... 8

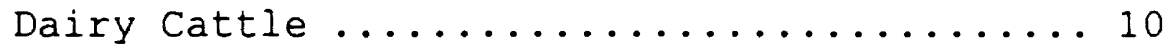

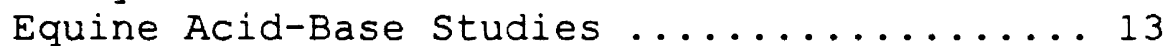

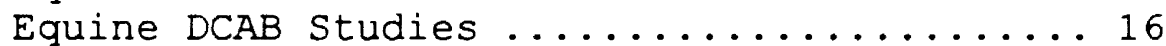

Exercise Effects on Blood Lactate ........ 18

III. MATERIALS AND METHODS ................ 23

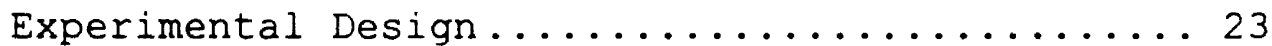

Training and Conditioning............... 24

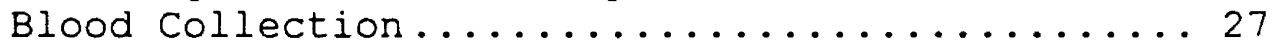

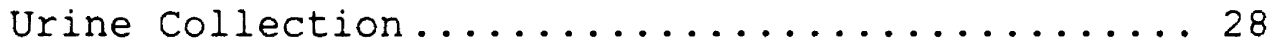

Urine Mineral Analysis................. 29

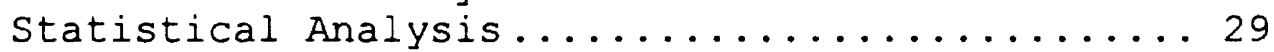

IV. RESULTS AND DISCUSSION ................ 30

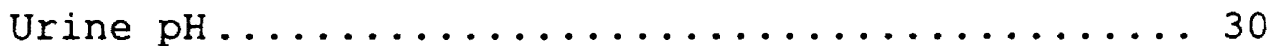

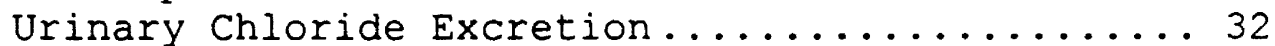

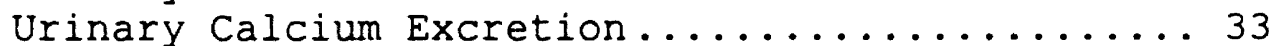

Blood Acid-Base Parameters............... 37

Blood $\mathrm{pH} \ldots \ldots \ldots \ldots \ldots \ldots \ldots \ldots \ldots \ldots \ldots$

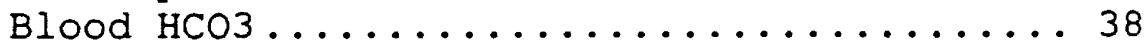

Blood pCO2 ....................... 43

Blood tCO2 ....................... 44

Blood po2 .......................45

$\mathrm{BEb}, \mathrm{BEecf} \ldots \ldots \ldots \ldots \ldots \ldots \ldots \ldots \ldots$

Blood Lactate Concentration.............. 55

Heart Rates and SET Times...............61 


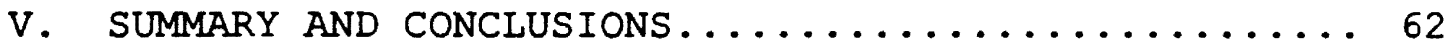

LITERATURE CITED......................... 63 


\section{LIST OF TABLES}

Table

Page

I. Composition of Diets, DM Basis............. 25

II. Diet Analysis, DM Basis ............... 26

III. Effect of Dietary Cation-Anion Balance on Urine $\mathrm{pH}$ in the Anaerobically Exercised

Horse ........................... 31

IV. Effect of Dietary Cation-Anion Balance on Chloride Excretion in the Anaerobically

Exercised Horse ..................... 35

V. Effect of Dietary Cation-Anion Balance on Calcium Excretion in the Anaerobically

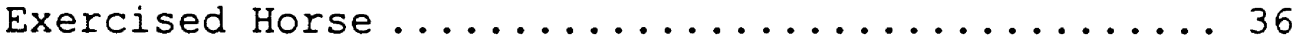

VI. Effect of Dietary Cation-Anion Balance on Arterial Blood pH in the Anaerobically

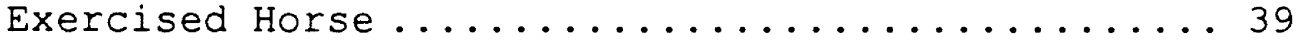

VII. Effect of Dietary Cation-Anion Balance on Venous Blood $\mathrm{pH}$ in the Anaerobically

Exercised Horse ..................... 40

VIII. Effect of Dietary Cation-Anion Balance on Arterial Blood $\mathrm{HCO} 3$ in the Anaerobically

Exercised Horse ...................... 41

IX. Effect of Dietary Cation-Anion Balance on Venous Blood $\mathrm{HCO}$ in the Anaerobically

Exercised Horse ...................... 42

X. Effect of Dietary Cation-Anion Balance on Arterial Blood pCO2 in the Anaerobically Exercised Horse ..................... 46

XI. Effect of Dietary Cation-Anion Balance on Venous Blood pCO2 in the Anaerobically Exercised Horse ..................... 47 
Table

XII. Effect of Dietary Cation-Anion Balance on Arterial Blood TCO2 in the Anaerobically

Exercised Horse...................... 48

XIII. Effect of Dietary Cation-Anion Balance on

Venous Blood TCO2 in the Anaerobically

Exercised Horse........................ 49

XIV. Effect of Dietary Cation-Anion Balance on Arterial Blood po2 in the Anaerobically

Exercised Horse...................... 50

XV. Effect of Dietary Cation-Anion Balance on Venous Blood pO2 in the Anaerobically

Exercised Horse....................... 51

XVI. Effect of Dietary Cation-Anion Balance on Arterial Blood Base Excess in the Anaerobically Exercised Horse............. 52

XVII. Effect of Dietary Cation-Anion Balance on Venous Blood Base Excess in the Anaerobically Exercised Horse............. 53

XVIII. Effect of Dietary Cation-Anion Balance on Arterial Base Excess Extracellular Fluid in the Anaerobically Exercised Horse......... 56

XIX. Effect of Dietary Cation-Anion Balance on Venous Base Excess Extracellular Fluid in the Anaerobically Exercised Horse......... 57

XX. Effect of Dietary Cation-Anion Balance on Blood Lactate Concentrations in the Anaerobically Exercised Horse.............. 58

XXI. Effect of Dietary Cation-Anion Balance on Recovery Heart Rates in the Anaerobically Exercised Horse..................... 59

XXII. Effect of Dietary Cation-Anion Balance on Standard Exercise Test Times in the Anaerobically Exercised Horse.............. 60 


\section{CHAPTER I}

INTRODUCTION

Competition and economics are the underlying mechanisms which drive the horse industry. A tenth of a second in a Thoroughbred or Quarter Horse race or a half of a point in a cutting or reining competition could mean the difference between first or second place, being a champion or not, or even whether or not ecomomics limit competition next year. Many areas of equine nutrition have been studied for their physiological impacts on equine performance. A relatively new area of research with horses is that of dietary cationanion balance (DCAB). The effects $D C A B$ has on production, including acid-base status, buffering capacity of the blood and calcium metabolism has been studied extensively in other species such as poultry, dairy cattle and swine. DCAB and its effects on acid-base status and mineral balance in the equine have begun to be quantitated. At present however, the NRC (1989) has no specific recommendations of DCAB for any category of horses. By quantifying an optimum DCAB for the various categories of horses, production may be improved as reflected in exercise performance, growth and possibly digestibility and utilization of nutrients. Recently, DCAB 
has generated an interest from equine researchers, and with further work DCAB could possibly answer some of the myths questions about feeding the performance horse and thereby enabling it to achieve its full genetic potential.

It is necessary to continue research in the area of $D C A B$ to determine whether or not it elicits positive effects on equine performance. The purpose of this project was to determine the effects of DCAB on anaerobically exercised horses. Therefore the objectives of this study were: 1)To determine the effect of varying $D C A B$ on urine $\mathrm{pH}$, and calcium and chloride excretion in the urine; 2) To determine the effect of varying $\mathrm{DCAB}$ on blood $\mathrm{pH}$ and blood gases; 3 ) To determine the effect of varying $D C A B$ on blood lactate; 4) To determine if performance is enhanced or hindered by varying DCAB as measured by recovery and standard exercise test (SET) times. 
CHAPTER II

LITERATURE REVIEW

Overview of Dietary Cation-Anion Balance

The equation, $\mathrm{mEq}(\mathrm{Na}+\mathrm{K})-(\mathrm{Cl}) / 100 \mathrm{~g}$ diet dry matter, is the original equation used to determine dietary cation-anion Balance (DCAB) (Mongin 1980). This equation takes into acount the monovalent elements sodium, potassium, and chloride as they appeared to have the greatest metabolic impact on acid-base physiology as they are the most readily absorbed minerals in the gut. These inorganic elements are also the major ions involved in the regulation of osmotic pressure in body fluids. Sulfur has been shown to have a similar DCAB lowering effect as chloride in dairy cattle (Tucker et al., 1991 and Oetzal 1991) and was included in the equation. The overall acid or base generating power of a diet can then be calculated as $\mathrm{mEq}(\mathrm{Na}+\mathrm{K})-(\mathrm{Cl}+\mathrm{S}) / \mathrm{kg}$ diet dry matter. $D C A B$ equations uses milliequivalent units ( $\mathrm{mEq})$, instead of milligrams since these elements exert their physiological effects on the body according to their valence rather than their weight. The equation results depend on the percent of sodium, potassium, chloride and 
sulphur in the diet. A higher number is indicative of more base generating power (cationic), and conversely a lower number indicates a more acid generating power (anionic).

DCAB Research in Other Species

$\underline{\text { Rabbit }}$

The earliest research reported of the cation-anion balance of the diet effecting the physiological aspects of production was by Morgen and Beger (1915). Their trial suggested that sodium carbonate had a greater effect than sodium chloride in increasing the mineral content in the bone of the rabbit. It was suggested that the alkaline reserve was increased due to the carbonate salt. These researchers also suggested that deficiencies in calcium, sodium, potassium, and magnesium could be induced by manipulating the cation-anion balance of the diet. Thacker (1959) showed that the failure of rabbits to grow and to maintain normal blood hemoglobin and bone ash levels when fed a basal diet containing a timothy hay grown in heavily fertilized soils was corrected when this diet was supplemented with salts of sodium, potassium, calcium or magnesium. He suggested that these cations could carry an anion which could be metabolized to $\mathrm{CO} 2$ and $\mathrm{H} 2 \mathrm{O}$ by the animals body. Salts of these elements carrying a chloride or sulfate anion fed at the same milliequivalent level were 
ineffective. Furthermore, it was suggested that under the dietary conditions of this experiment, the rabbits suffered a physiological cation-anion imbalance or acidosis and that this condition was interrelated with mineral metabolism of the animal. It was shown that this mineral imbalance induced calcium and potassium deficiencies in the presence of apparent adequate dietary levels of these elements.

\section{Poultry}

Poultry nutritionists have extensively researched the balance of the elements sodium, potassium and chloride in the diet and the effect these have on production. Mongin (1968) found that egg shell calcification altered acid-base status of the laying hen, which sparked an interest in methods to alter the acid-base status of the hen to improve eggshell strength and thickness. This study sparked specific research which attempted to determine the effects of $D C A B$ on egg shell strength and thickness (Austic 1984, Hamilton and Thompson, 1980; Cohen et al, 1974 Sauveur and Mongin, 1971)

Such work as Cohen, et al. (1972) analyzed the effects of sodium to chloride ratios on blood pH, $\mathrm{HCO} 3, \mathrm{pCO} 2, \mathrm{Na}+$ and $\mathrm{Cl}$ - in laying hens. These authors determined that the sodium:chloride ratio in the diet could produce a respective alkalosis or acidosis depending on that ratio. This was displayed by an alkalosis produced by a constant level of 
dietary chloride fed with an excess dietary sodium. Conversely, a constant level of sodium fed with an excess dietary chloride produced acidosis. They also stated that when equal amounts of sodium and chloride were added to the diet, there was no effect on acid base balance. Subsequently, the conclusion was that acid-base balance, as shown by blood $\mathrm{pH}$ and blood gases was a function of dietary sodium:chloride ratios rather than absolute amounts of each. Further work by Cohen and Hurwitz (1974) displayed the alkalogenic effects of supplemental sodium and potassium and the acidogenic effects of supplemental chloride in the diet of laying hens. This research displayed that potassium had the same alkalogenic effects on blood $\mathrm{pH}$ and $\mathrm{HCO} 3$ as sodium. Furthermore these findings suggested an additive effect of sodium and potassium to offset the metabolic acidosis produced by excess dietary chloride. This work concurs with that of Neshiem et al. (1964) who showed that addition of sodium and potassium by excess dietary chloride. Hamilton and Thompson (1980) displayed a decrease in blood pH, HCO3and eggshell strength in laying hens caused by increasing dietary chloride from .11 to 2.138 . Earlier work by Hunt and Aitken (1962) and Sauver and Mongin (1971) also showed excesive levels of dietary chloride depressed eggshell calcification. In addition, Frank and Beger (1965) and Mongin (1968) showed that a diet which increased the alkaline reserve of the laying hen would subsequently increase egg shell strength. 
$D C A B$ has also been linked to production traits such as growth in poultry (Neisham et al, 1984). This study demonstrated that unless the cations sodium and potassium were equimolar to the anions chloride and sulfate, excess dietary chloride or sulfate ions lowered growth significantly. Melliers and Forbes (1966) studied the effects of adding an acid, base or a combination of the two to the diet on growth and feed intake in chicks. They found that maximum gains and intakes were realized at ratios of 1.2 to 1.8 , and totally suppressed at a ratio of 0.6 , thus displaying that gains and intake were dependent on dietary cation-anion ratio. Researchers have reported that optimum growth is achieved with a dietary electrolyte balance of 250 to $300 \mathrm{mEq} / \mathrm{kg}$. (Mongin and Sauver, 1977; Johnson and Karunajeewa, 1985).

Dietary cation-anion balance has also been shown to influence bone disorders in poultry such as tibial dyschondroplasia (TD). Leach and Neshium (1972) determined that TD is affected by dietary cation-anion balance. Sauveur and Mongin (1978) showed that feeding excess dietary chloride increased the incidence of TD. It was shown by Halley et al. (1987) that base excess was negatively correlated with the frequency of TD and with three week body weights. 
Swine

As early as 1966, Liebholz et al. reported that 10 to 20 $\mathrm{g} / \mathrm{kg}$ of potassium acetate increased the growth rate and feed effieciencies in weanling pigs fed diets severely deficient in protein. Further, Madubuike (1980) and Austic et al (1983) similarly observed that the growth of young pigs fed lysine deficient diets responded to sodium or potassium bicarbonate. Austic et al. (1983) performed a second experiment to determine the upper and lower parameters of electrolyte balance of diets at which maximum growth can be achieved in young pigs. By using the equation $\mathrm{mEq}(\mathrm{Na}++$ $\mathrm{K}+1-(\mathrm{Cl}-) / \mathrm{kg}$ diet dry matter, six diets were formulated ranging from -100 to $500 \mathrm{DCAB}$. Although there were no statistically significant differences, they found that diets in the range of 100 to $300 \mathrm{mEq} / \mathrm{kg}$ DCAB diet dry matter produced optimum performance.

Yen et al. (1981) observed the effects calcium chloride had as a regulator of feed intake and weight gains in swine. An addition of $48 \mathrm{CaCl}$ to a basal diet lowered weight gains, feed intake and feed efficiency. The pigs fed $\mathrm{CaCl}$ also developed an acidosis displayed by a lowered $\mathrm{pH}, \mathrm{HCO} 3$, tCO2 and base excess. However, a 2.038 supplementation of dietary $\mathrm{NaHCO} 3$ restored the blood parameters to normal. In 1987, Patience et al. fed eight to twelve week old pigs five rations with $D C A B^{\prime} s$ ranging from -85 to +341 . These authors showed that growth and feed intake were optimum with pigs 
consuming those diets between 0 and 341 . Also, as the diet became increasingly acidogenic, a metabolic acidosis, accompanied by a reduced growth rate, was observed. Honeyfield et al. (1985) evaluated the metabolic and physiological consequences of feeding growing-finishing pigs varying levels of $\mathrm{Na}+$ and $\mathrm{Cl}$ - as assessed by changes in rate of gain, feed intake and gain:feed ratios and plasma concentrations of electrolytes and basic amino acids. These authors suggested that the $\mathrm{Cl}$ - requirement of the grower pig (36 to $58 \mathrm{~kg}$ ) should be fed at not more than .08\% and optimum gain is achieved at dietary $\mathrm{Na}$ levels of $.18 \%$. Further, for the finisher pig, $\mathrm{Na}+$ and $\mathrm{Cl}$ - should be fed at .13\% $\mathrm{Na}+$ and $.178 \mathrm{Cl}$ - for optimum average daily gain and feed efficiency.

In 1990, Golz and Crenshaw studied the effects of dietary sodium, potassium and chloride on growth in young swine. Weight gain was dependent upon the $\mathrm{K}+: \mathrm{Cl}$ - ratio with $\mathrm{K}+$ and $\mathrm{Cl}$ - having a reciprocal interaction. Gain was lowered by $.07 \mathrm{~kg} /$ day when dietary $\mathrm{Cl}$ - was increased to $.57 \%$ and fed with .18 dietary $\mathrm{K}+$. However, weight gain was increased by $.16 \mathrm{~kg} /$ day when dietary chloride was increased with 1.18 dietary $\mathrm{K}+$. Within the parameters of .038 to .608 dietary Nat, no interaction was found between sodium and potassium or sodium and chloride. 


\section{Dairy Cattle}

There has been many significant studies concerning the effects of $D C A B$ on production performance in dairy cattle (Block, 1984; Tucker et al. 1988, Beighle et al. 1990). In 1977, Kellaway et al. studied $\mathrm{NaCl}$ or $\mathrm{NaHCO} 3$ supplementation in diets of dairy calves. These authors examined levels of 2, 11, 20, or 29 grams of $\mathrm{NaCO} 3$ or $\mathrm{NaHCO}^{2}$ to determine the effect of these supplementations on feed intake, weight gains, and acid-base balance. The calves supplemented with NaHCO3 displayed a linear increase in growth and intake when fed the high $\mathrm{Na}+$ diet compared to the low $\mathrm{Na}+$ diet. Further, dry matter intake and growth were significantly different when calves consumed diets containing $29 \mathrm{~g} \mathrm{Na} / \mathrm{kg}$ dry matter (DM) compared to $2 \mathrm{~g} \mathrm{Na} / \mathrm{kg}$ DM pre-weaning. Dietary $\mathrm{NaCl}$ supplementation exhibited a significant effect only with a 168 higher intake when fed at $11 \mathrm{~g} / \mathrm{kg}$ DM versus $2 \mathrm{~g} / \mathrm{kg}$ DM An alkalosis was created only when NaHCO3 was fed at levels above $20 \mathrm{~g} \mathrm{Na} / \mathrm{kg}$ DM This was demonstrated by an increase in base excess and blood $\mathrm{pH}$.

Block (1984) studied the effect of DCAB on parturient paresis in dairy cattle. This study included sulfur in the equation and $D C A B$ was defined as $\mathrm{mEq}((\mathrm{Na}++\mathrm{K}+)-(\mathrm{Cl}-+\mathrm{S}-$ ))/100g diet DM. He demonstrated that by feeding a highly anionic diet of $-12.85 \mathrm{mEq} / 100 \mathrm{~g}$ diet $\mathrm{DM}$, parturient paresis could be prevented. It was determined that although diets contained a high Ca:P ratio, mobilization of calcium may 
have occurred during the calcium stress period of lactation due to the acidity of the diet. He further explained this could have been a result of the liver and kidney's response to a drop in blood $\mathrm{pH}$ causing a systemic calcium mobilization from the bone. In 1991, Goff and others researched the effects of chloride addition to a highly cationic prepartum diet of dairy cows. They found that cows fed the highly anionic diet synthesized 1,23 dihydroxyvitamin D more optimally, due to increased parathyroid hormone, which also increased intestinal calcium absorption. Also, they were in agreement with Block, (1984) that a nutritionally induced metabolic acidosis causes bone calcium resorption.

Tucker et al. (1988) determined the effects of DCAB on milk, blood, urine, and rumen fluid in lactating Holsteins. They found that by increasing DCAB from -10 to $+20 \mathrm{mEq} / 100 \mathrm{~g}$ diet dry matter created a linear increase in blood $\mathrm{pH}$ and bicarbonate and also increased milk yields by 8.68 . It was noted that all differences except for blood bicarbonate and rumen isovalerate could be attributed to the dietary cationanion balance itself rather than to the effects of a single ion. Homeostatic mechanisms have been developed to maintain the critical constant blood pH. Two of the functions which maintain this constant ratio of blood $\mathrm{HCO}-$ to $\mathrm{pCO} 2$ are: The adjustment of respiration rate to control blood pCO2 and the adjustment of renal excretion of bicarbonate to control blood bicarbonate concentration. 
Beighle et al. (1990) determined that dairy calves fed diets with a low DCAB had lower bone phosphorus concentrations while also displaying higher levels of blood phosphorus and fecal phosphorus when compared with calves fed diets with a high DCAB. There was also an amplification of these effects when the low DCAB was made phosphorus deficient and fed to these calves. This indicates an interaction between $\mathrm{DCAB}$ and dietary phosphorus on changes seen in blood, fecal and bone phosphorous concentrations. A similar study by Tucker et al. (1991). These authors found that feed intake was not affected by $\mathrm{KCl}$ or $\mathrm{NaHCO}_{3}$ supplementation. However, average daily gain increased with increased potassium and tended to be reduced by increased dietary sodium bicarbonate. Also, $\mathrm{NaHCO} 3$ supplementation appeared to reduce urinary calcium excretion and increase urine $\mathrm{pH}$. This study indicated that potassium requirements for the growing calf is between .408 and .558 diet DM and that average daily gain and plasma potassium are sensitive indicators of dietary potassium in the growing calf.

Also in 1991, Tucker et al. evaluated the influence of dietary sulfur versus chloride on systemic acid-base status, milk yield, milk composition, and mineral metabolism in lactating dairy cows. Results were similar to those of Tucker et al. (1988) in that blood pH and HCO3- were lowered by supplementation of dietary chloride and sulfur. Further, urinary hydrogen concentration was lowered by reducing DCAB with either chloride or sulfur. Milk fat was highest in 
cows consuming supplemental sulfur. Apparent absorption of chloride by ruminants may exceed 958 (Church and Fontenot, 1979), whereas apparent absorption of sulfur in Hereford steers has ranged from 51.8 to 60.88 (Spears et al.. 1985). The impact of sulfur on systemic acid-base status might be less than that of $\mathrm{Cl}$ - because of the lower sulfur absortion (Tucker et al.,1991). Moreover, these authors stated that the variety of organic and inorganic forms in which sulfur may be absorbed and utilized by the body adds to the variability of it's effect on acid-base status. However, regardless of the variability involved when measuring the impact of $\mathrm{S}$ on systemic acid-base status, the similar effects of $\mathrm{Cl}$ and $\mathrm{S}$ on acid-base status in these researcher's study indicate that the contribution of $S$ on acid-base status should not be ignored.

\section{Equine acid-base studies}

Milne (1974) conducted a series of experiments to evaluate blood gases, acid-base balance, electrolyte and enzyme changes in exercising horses. He showed that there was no change in acid-base balance during moderate work, but all horses developed a partially compensated metabolic acidosis during heavy work. There appeared to be a linear relationship between changes in arterial and venous blood $\mathrm{pH}, \mathrm{pCO} 2, \mathrm{HCO}$, lactic acid concentration and exercise. Furthermore, in order to reach the anaerobic threshold in 
unconditioned horses, exercise must exceed a work rate of $350 \mathrm{~m} / \mathrm{min}$. and approach a work rate of $600 \mathrm{~m} / \mathrm{min}$. It is interesting to note that during the endurance portion of this experiment, horses experienced an alkalosis, indicating that $\mathrm{NaHCO} 3$ supplementation could increase the severity of the alkalosis.

Williamson (1974) reviewed the literature for normal electrolyte values in equine species and found a wide range for serum electrolyte levels of ( $\mathrm{Na}+, \mathrm{K}+, \mathrm{Cl}-$, and $\mathrm{HCO}_{-}-$). He looked at these blood electrolyte levels in 200 winning performers and found mean values of $141,3.8,101$, and 27 for blood $\mathrm{Na}+, \mathrm{Kt}, \mathrm{Cl}-$, and $\mathrm{HCO} 3-$ respectively. He stated that in the literature reviewed, deviations from normal electrolyte levels of race horses occur, both in deficiencies and excesses or more specifically, acidotic or alkalotic conditions. Furthermore, if these deviations are uncorrected, the effect on performance can be significant.

Lawrence et al. (1987) evaluated the effects of $\mathrm{NaHCO}$ administration during exercise and recovery in exercising horses. She evaluated the effects of ingestion of $\mathrm{NaHCO}$ on acid-base status which could augment the bicarbonate buffer system in the blood. This might aid horses in competitions where they experience a metabolic acidosis. It was determined that by drenching horses with $300 \mathrm{mg} / \mathrm{kg}$ body weight of $\mathrm{NaHCO}^{1.5-2.5}$ hours prior to the exercise test, time to fatigue could be extended. Furthermore, blood lactic acid level increased throughout exercise and was 
approximately 408 higher with the administration of $\mathrm{NaHCO}$ than for the placebo treatment. This would indicate a greater physiological capablity for the body to clear lactate from the muscle with the administration of $\mathrm{NaHCO}$ thus lengthening time to fatigue. Further research by Lawrence et al (1990) determined similar results when horses were drenched with $\mathrm{NaHCO} 32.5$ hours prior to racing. These authors reported faster racing times with $\mathrm{NaHCO} 3$ administration and once again reported a greater capability of the blood bicarbonate buffering system to promote lactic acid efflux from the muscle due to $\mathrm{NaHCO} 3$ ingestion 2.5 hours prior to racing.

Kelso et al. (1987) found by administering . $4 \mathrm{~g} \mathrm{NaHCO} / \mathrm{kg}$ diet $\mathrm{DM}$ one hour before race that blood $\mathrm{pH}$ and $\mathrm{HCO}-$ were significantly elevated $(p<.05)$ prior to exercise. This is in agreement with Lawrence et al. (1987). However, findings that there are no differences between blood $\mathrm{pH}, \mathrm{HCO}-$ and lactic acid disagrees with Lawrence et al. (1987). Kelso et al. (1987) stated that their results do not support the contention that administration of $\mathrm{NaHCO} 3$ improves the intracellular environment which could allow metabolic pathways to operate beyond normal levels. However, the difference in the timing of administration could account for the discrepency in the findings. 
DCAB Studies

In 1989, Topliff et al. studied the changes in urinary and serum calcium and chloride concentrations in exercising mares fed a low $(+6.5 \mathrm{mEq} / \mathrm{kg})$ versus a high $(+150 \mathrm{mEq} / \mathrm{kg})$ DCAB. The effects of these diets were also evaluated on low versus high ambient temperatures. Horses consuming the low DCAB excreted more calcium $(84.7 \mathrm{mg} / \mathrm{dl})$ and chloride $(176.1 \mathrm{mg} / 1)$ versus horses consuming the high DCAB which excreted $9.2 \mathrm{mg} / \mathrm{d}$ and $124.8 \mathrm{meq} / \mathrm{l}$ for calcium and chloride respectively. There were no changes oobserved in serum calcium or chloride concentration. These authors suggested that horses consuming diets containing excess anions could be in a net negative calcium balance.

Baker et al. (1992) studied the effects of DCAB on acidbase status in sedentary horses and displayed the acid generating power of a highly anionic diet and the base generating power of a highly cationic diet as shown by significant changes in urine $\mathrm{pH}$. These diets were formed by supplementing ammonium chloride and calcium chloride to form diet low (L), calcium chloride to form diet medium low (ML), and sodium bicarbonate and potassium citrate to form diet high (H). Calculated DCAB's were +21 (L), +125 (ML), +231 (MH) and +350 (H) $\mathrm{mEq} / \mathrm{kg} \mathrm{DM}$. Like Topliff et al. (1989), Baker et al., (1992) showed increased calcium and urine excretions as DCAB decreased. Values were significantly different $(p<.05)$ between diets $L$ (39.82), medium ML 
(31.80), MH (13.99) and $\mathrm{H}$ (3.99) for urinary calcium excretion. For urinary chloride excretion, diets L (70.60) and ML (57.54) were significantly different $(p<.05)$ decreases in blood $\mathrm{pH}, \mathrm{pCO} 2$ and $\mathrm{HCO} 3$ as $\mathrm{DCAB}$ decreased. This complies with results by stutz and coworkers (1992) who studied the effects of $D C A B$ on blood parameters in the exercising horse. Dietary supplementations were similar to Baker et al. (1992) and provided diets fed with DCAB's of $+5(\mathrm{~L}),+107(\mathrm{ML}),+201(\mathrm{MH})$ and $+327(\mathrm{H}) \mathrm{mEq} / \mathrm{kg}$ dry matter. This research showed that strenuously exercised horses experience a nutritionally induced metabolic acidosis when fed highly anionic diets. At rest, horses consuming diet $\mathrm{L}$ had lower venous blood $\mathrm{pH}, \mathrm{pCO} 2$ and $\mathrm{HCO} 3$ concentrations as compared to those consuming diets $\mathrm{MH}$ and $\mathrm{H}$. However, no differences were observed in blood $\mathrm{pH}$ or acid-base parameters between dietary treatments post anaerobic exercise.

Wall et al. (1992) researched the effects of $D C A B$ on urine $\mathrm{pH}$ and mineral excretion in exercising horses during the same trial as Stutz et al. (1992). Like Topliff et al. (1989), and Baker et al. (1992), they observed a decrease in urine $\mathrm{pH}$ with decreasing $\mathrm{DCAB}$ and as well, increased calcium and chloride excretion with horses consuming highly anionic diets. Furthermore, horses consuming diet $\mathrm{H}$ excreted more sodium than those consuming diets MH, ML, and L. Horses consuming diet $\mathrm{L}$ in this trial could have been in a net negative calcium balance which could eventually lead to an osteoporotic weakening of the skeletal system. Wall et al. 
(1993) displayed that calcium balance was significantly higher for horses consuming the +327 DCAB $(H)$ versus the +5 $D C A B$ (L) diet. Also sodium balance was higher for horses consuming diet $H$ versus diets $M L$ and $L$. Also chloride balance was higher and magnesium and phosphorus balances were lower $(p<.05)$ for horses consuming diet $L$. However, potassium and sulfur balances were not significantly affected by DCAB. Furthermore, dry matter digestibility was lower and subsequently fecal output greater $(\mathrm{p}<.05)$ in horses consuming diet $\mathrm{L}$ versus diet $\mathrm{H}$. These authors stated that depending on the level of intake, horses ingesting highly anionic diets may experience negative calcium, phosphorus and magnesium balances.

\section{Exercise Effects on Blood Lactate}

Maximal exercise results in the production and accumulation of large amounts of lactate in muscle, which in turn increases blood levels. Snow et al. (1985) reported lactic acid concentrations in the blood in excess of 34 mol/L. These researchers studied metabolic responses in four thoroughbred horses that performed a standard exercise test consisting of four intermittent maximal gallops. Muscle biopsy samples and jugular vein blood samples were taken before, during and after exercise and assayed for ATP and intermediary metabolites. In three of the horses, who were clearly fatigued, muscle and blood ATP decreased by up 
to $50 \%$ by the end of the fourth gallop. This was matched by pronounced accumulations of glycerol 3-phosphate, glycerol, and lactate after exercise. Post-exercise there was little or no recovery in muscle ATP or lactate during the thirty minutes.

Marlin et al. (1987) studied the effect of lactate recovery kinetics and the effect of different intensities of post exercise activity on recovery in the horse. Recovery protocols included standing (S), walking (W) and trotting and walking $(\mathrm{T})$. ( $\mathrm{T}$ ) displayed a near two-fold increase in the rate of muscle lactate disappearance when compared to (S) and (W). However, half-times for blood lactate disappearance with $(T),(W)$ and $(S)$ were $12.2 \pm 3.9,16.9$ \pm 4.3 and $26.8 \pm 5.2$ minutes $(T<W<S, p<.01)$. These authors suggested that lactate transport from the muscle is carrier mediated, and that the carrier is saturated even at low concentrations of lactate. They also stated that if this were true, then differences in blood flow through the muscle bed would be unlikely to affect the rate of efflux, implying that the difference in muscle lactate dissappearance rates between (S) and ( $T$ ) recoveries resulted from differences in the rates of local utilization ie. glycogen synthesis and oxidation. Further, they suggested the possibility of recovery in gradients is linked to recovery in muscle $\mathrm{pH}$. This was shown by trotting recovery (T) causing blood pH to increase more rapidly when compared to (S) which on this basis would favor an increase in muscle lactate efflux. The 
ability to rapidly remove metabolites during exercise from both muscle and blood could be considered a distinct physiological advantage to an athlete. This was displayed by the most capable of the five horses in Marlin and coworker's (1987) trial. In general, where the capacity of muscle to release lactate was high, then the fall in concentration in blood was slower.

Webb and others (1988) studied physiological responses in cutting horses performing an exhaustive cutting performance test. They determined that the cutting horses' capacity for performance was enhanced by training, specifically for the work as indicated by reduced heart rate and blood lactate concentration (LA). Heart rate and LA values indicated that cutting-type work is strenuous and employs glycolytic pathways to produce sufficient energy for short duration, high-velocity exercise.

Miller and Lawrence (1987) also discussed heart rate and lactate as indicators of cardiovascular fitness and oxygen delivery to muscle. These authors showed that conditioning resulted in lower $(p<.01)$ blood lactate concentrations during exercise and recovery. Also, in the unconditioned horses, lactate remained elevated throughout the sixty-minute recovery period, while in the conditioned horses, lactate had returned to pre-exercise levels by the sixtieth minute of recovery. In this trial, heart rates were similar in that unconditioned horses displayed $62.6 \pm$ 7.3 and $206.6 \pm 3.1$ beats per/minute (bpm) for resting and 
last minute of excercise respectively. Conditioned horses had heart rates of $69.0 \pm 6.8 \mathrm{bpm}$ at rest and $188.5 \pm 3.4$ bpm at the last minute of exercise. The decreased lactate levels observed in this submaximal exercise test are consistent with submaximal training effects which have been described previously in horses (Milne et al., 1976; Thornton et al., 1983). These authors similarly suggested that lower blood lactate levels during submaximal exercise in trained individuals are generally associated with metabolic changes within the muscle fiber which allows for greater oxidative energy production.

Work performed by Miller and others (1988) studied whether or not differences exist in blood lactate, pyruvate $\mathrm{pH}, \mathrm{pCO} 2$ and $\mathrm{pO} 2$ in blood collected from three locations (jugular vein, carotid artery and pulmonary artery). There were no significant differences found in the parameters measured at rest except for po2. Similarly, at the sixtieth minute of recovery, only $\mathrm{pO} 2$ and $\mathrm{pCO} 2$ were different between locations. However, at $4.5 \mathrm{~m} / \mathrm{sec}$ on a treadmill set at an 118 grade, there were differences primarily in the pulmonary artery when compared to the other two locations. Blood pH and po2 were highest in the carotid artery and lowest in the pulmonary artery. During exercise, pCO2 increased in the pulmonary artery and decreased in the jugular vein and the carotid artery. Lactate was elevated after exercise by exercise but was not different between sources, suggesting that lactate concentrations in samples collected from the 
jugular vein are representative of central circulation. However, the same does not appear to be true for pyruvate as it was higher in the pulmonary artery than in the jugular vein or carotid artery.

From the information reviewed in the literature cited in this paper, it is aparent that changes in the mineral balance of the diet, or more specifically DCAB, does have an effect on the acid-base status of the animal. Furthermore, is appears that production or athletic performance of the animal may be influenced by manipulation of dietary cationanion balance.

Therefore, this experiment was undertaken to determine the effect of varying $D C A B$ on blood and urine $\mathrm{pH}$, blood bicarbonate, pCO2, p02, TCO2, BEb, BEecf and lactate and performance in horses performing anaerobic work. 
CHAPTER III

MATERIALS AND METHODS

Experimental Design

Four mature geldings (two Quarter Horses, one Appaloosa and one $1 / 2$ Quarter Horse 1/2 Arabian) were used in a $4 \times 4$ Latin square experiment designed to study the effects of $D C A B$ on the acid-base status, work performance, LA concentration and recovery heart rates in anaerobically exercised horses. The horses were randomly assigned to four dietary treatments. The trial consisted of four fifteen day experimental periods and four dietary treatments.

Diets consisted of a pelleted base concentrate of corn, soybean meal and cottonseed hulls, and was produced at the Oklahoma state University Feedmill. The four experimental horses were individually housed in $12^{\prime} \mathrm{X} 12^{\prime}$ stalls and received standard animal health care throughout the trial. Horses were fed at 11 AM and 11 PM daily and were weighed weekly to monitor body weight. Diets were fed for 12 days prior to the beginning of sample collection. The concentrate was fed in a 60:40 ratio with native prairie grass hay grown at the OSU Beef Research Center. The horses 
were fed at levels required to maintain constant body weight throughout the experiment. The four dietary treatments (Table I) were formed by the addition of $.30 \%$ calcium chloride and .408 ammonium chloride to diet low (L), .308 calcium chloride to diet medium low (ML) and 1.208 potassium citrate and .708 sodium bicarbonate to diet high (H). Diet medium high $(\mathrm{MH})$ received no supplementation and served as the control ration. Diets were calculated to contain 2.5 Mcal/kg DM and 9.68 crude protein for all treatments (Table II). Diets contained approximately equal amounts of calcium, phosphorous, magnesium and sulphur. After supplementation, it was determined that diet $\mathrm{H}$ contained $1.25 \%$ potassium and .408 sodium, diet ML contained .738 chloride and diet $L$ contianed 1.048 chloride. The variation of these minerals in the dietary treatments gave DCAB's of +10 (L), +95 (ML), +165 (MH) and +295 (H) .

Training and Conditioning

Horses were aerobically conditioned $6 d /$ wk for 4 weeks prior to the beginning of the experiment using a Long slow Distance (LSD) training regimen which consisted of a $3.28 \mathrm{~km}$ gallop at target heart rates of $160 \mathrm{bpm}$. The conditioning period was to ensure that aerobic fitness was standardized among the four experimental horses. During the experimental periods, horses were exercised $6 \mathrm{~d} /$ wk alternating ISD with $2 d / w k$ sprint training. Sprint training consisted of 
TABLE I. COMPOSITION OF DIETS, DM BASIS.

\begin{tabular}{|c|c|c|c|c|}
\hline \multirow[b]{2}{*}{ Ingredient $(8)$} & \multicolumn{4}{|c|}{ Diet } \\
\hline & $\mathrm{L}$ & ML & $\mathrm{MH}$ & $\mathrm{H}$ \\
\hline Corn & 37.10 & 37.10 & 37.10 & 37.00 \\
\hline Soybean Meal & 6.30 & 6.50 & 6.80 & 6.80 \\
\hline Cottonseed Hulls & 14.90 & 15.10 & 15.10 & 13.00 \\
\hline Dicalcium Phosphate & .50 & .50 & .50 & .40 \\
\hline Limestone, ground & --- & --- & .50 & .40 \\
\hline Trace Mineral Salt & .50 & .50 & .50 & .50 \\
\hline Calcium Chloride & .30 & .30 & --- & --- \\
\hline Ammonium Chloride & .40 & --- & -- & --- \\
\hline Potassium Citrate & --- & --- & --- & 1.20 \\
\hline Sodium Bicarbonate & --- & --- & -- & .70 \\
\hline Native Grass Hay & 40.00 & 40.00 & 40.00 & 40.00 \\
\hline Total & 100.00 & 100.00 & 100.00 & 100.00 \\
\hline $\mathrm{DCAB}, \operatorname{meq}((\mathrm{Na}+\mathrm{K})-(\mathrm{Cl}+\mathrm{S}) / \mathrm{kg}$ & 10 & 95 & 165 & 295 \\
\hline
\end{tabular}


TABLE II

TREATMENT ANALYSIS, DRY MATTER BASIS

\begin{tabular}{lcccc}
\hline & \multicolumn{4}{c}{ Treatment } \\
\cline { 2 - 4 } Constituent & L & ML & MH & H \\
\hline DE, Mcal/kg & 2.60 & 2.60 & 2.60 & 2.60 \\
Crude Protein, 8 & 10.20 & 10.20 & 10.20 & 10.20 \\
Calcium, 8 & .44 & .44 & .51 & .47 \\
Phosphorus, 8 & .29 & .29 & .29 & .29 \\
Magnesium, 8 & .15 & .15 & .15 & .15 \\
Potassium, 8 & .72 & .72 & .72 & .93 \\
Sulfur, 8 & .11 & .11 & .11 & .11 \\
Sodium, 8 & .24 & .24 & .24 & .44 \\
Chloride, 8 & .90 & .61 & .40 & .40 \\
DCAB & +10 & .95 & +165 & +295 \\
\hline
\end{tabular}


one $.8 \mathrm{~km}$ sprint at heart rates above $200 \mathrm{bpm}$. On the last day of each 15 day experimental period, horses performed a standardized exercise test (SET) approximately two hours after the morning feeding. The SET consisted of a $1.64 \mathrm{~km}$ sprint at speeds sufficient to elicit target heart rates of between 200 and $210 \mathrm{bpm}$. Heart rates were recorded using a digital onboard heart rate monitor (UNIQ Computer Instruments Corp. Hempstead, NY) .

\section{Blood Collection}

Arterial (A) and Venous (V) blood samples were taken via indwelling catheters pre-exercise (P), immediately after exercise (0), and at $1,2,3,4,5,10,30$, and 60 minutes of recovery (REC). Prior to the the SET, the carotid artery and jugular vein were catheterized and sutured for stability during exercise with 18 and 14 gauge $x 11 / 2$ inch catheters respectively. Arterial samples taken were simplified due to prior carotid arterial loop surgery performed on all experimental horses in this trial which raised the carotid artery to the subcutaneous level. Samples for analysis were drawn for each time into a $12 \mathrm{cc}$ syringe for $\mathrm{A}$ and $\mathrm{V}$ blood and $7 \mathrm{ml}$ and $3 \mathrm{ml}$ of each were transferred into lithium heparin blood tubes for $L A$ and blood gas samples respectively. After each collection, $3 \mathrm{ml}$ of heparinized saline was injected into the catheter to prevent clotting. Samples for determination of IA were immediately 
deproteinized after collection in $108 \mathrm{w} / \mathrm{v}$ trichloroacetic acid, centrifuged and the supernatant decanted and stored. $A$ and $V$ blood samples were then placed into an ice water slurry until analyzation. Lactic acid concentrations were determined using an enzymatic assay (Sigma Lactate Procedure No. 826-UV). Another sample was immediately analyzed for $\mathrm{pH}, \mathrm{HCO} 3, \mathrm{pCO} 2, \mathrm{tCO} 2, \mathrm{tO} 2, \mathrm{BEecf}$ and $\mathrm{BEb}$ on a blood gas analyzer (Instrumentation Laboratory Model 1304, Lexington, Ma.).

\section{Urine Collection}

Seventy two hours prior to the SET, total urine was collected every four hours using urine harnesses. At each four hour collection, total volume for each horse was recorded. A sample (10\% of the total volume) was composited for each horse and time period through the 72 hours of collection. One $50 \mathrm{ml}$ sample was taken and immediately frozen for chloride analysis. Another $50 \mathrm{ml}$ sample was taken and urine $\mathrm{pH}$ was determined using a Fischer Accumet Model $950 \mathrm{pH}$ meter with a standard glass body combination electrode which accounts for sample temperature. This $\mathrm{pH}$ meter was standardized before each four collection. After pH analysis these samples were acidified with concentrated $\mathrm{HCl}$ at $3 \%$ of total volume and samples immediately frozen for later mineral analysis. 
Urine Mineral Analysis

Calcium content of the urine was evaluated on a PerkinsElmer Model 4000 Atomic Absorption Spectrophotometer. The composite samples were diluted with a .5\% lanthanum +.18 potassium solution at a dilution rate of $1: 937.10$ and used a 4 parts per million standard. Samples were read at 422.7 nanometers.

Urine chloride concentration was determined via potentiometric titration by using a HBl Digital Chloridometer (Haake Buchler Instruments, Inc.).

\section{Statistical Analysis}

Data for urine $\mathrm{pH}$, blood $\mathrm{pH}$, blood gases, blood lactate concentrations and heart rates were analyzed using a general linear model for repeated measures, with horse, period and treatment as main effects and time as the repeated variable. Data for urine minerals and SET times were analyzed using the general linear models procedure with horse, period and treatment as the main effects. Treatment least squares means over time were then calculated and tested for significance using the pdiff procedure(SAS, 1985). 
CHAPTER IV

RESULTS AND DISCUSSION

Urine $\mathrm{pH}$

Urine $\mathrm{pH}$ was lower $(\mathrm{p}<.001)$ for horses consuming diet $\mathrm{L}$ and higher $(p<.01)$ for horses on diet $H$ when compared to treatments ML and MH. The effect of treatment over time on urine $\mathrm{pH}$ is shown in Table III. Least square means ranged from 5.88 to 6.14 on diet $L, 7.23$ to 7.51 on diet ML, 7.30 to 7.55 on diet $\mathrm{MH}$ and 7.83 to 8.03 on diet $\mathrm{H}$. This data concurs with that of Baker et al., (1991), Wall et al., (1991) and Tucker et al., (1988), demonstrating the systemic acid generating power of anions, and the systemic base generating power of cations. More specifically, as excess chloride is filtered from blood and excreted in urine, it is accompanied by either hydrogen, sodium or potassium. When hydrogen ions accompany chloride, urinary $\mathrm{pH}$ decreases. However, $\mathrm{HCl}$ would damage the tubule lumen, and is subsequently excreted as ammonium chloride. The excretion of sodium in urine is always in the form of a sodium salt, namely $\mathrm{NaCl}$ or $\mathrm{NaHCO}$. Since there was excess dietary sodium in diet $\mathrm{H}$, there would be more sodium excreted as 
TABLE III

\section{EFFECT OF DIETARY CATION-ANION BALANCE ON URINE PH POST FEEDING IN EXERCISED HORSES}

\begin{tabular}{|c|c|c|c|c|c|}
\hline \multirow[b]{2}{*}{ Time } & \multicolumn{5}{|c|}{ Treatment } \\
\hline & I & MI & MH & $\mathrm{H}$ & S.E. \\
\hline $11 \mathrm{am} \star$ & $5.88^{a}$ & $7.41^{b}$ & $7.51^{b}$ & $7.91^{\mathrm{C}}$ & .103 \\
\hline $3 p m$ & $6.03^{a}$ & $7.23^{b}$ & $7.55^{b}$ & $8.02^{C}$ & .109 \\
\hline $7 \mathrm{pm}$ & $5.89^{a}$ & $7.29 b$ & $7.30^{b}$ & $7.83^{C}$ & .096 \\
\hline $11 \mathrm{pm} \star$ & $5.97^{a}$ & $7.28^{\mathrm{b}}$ & $7.47^{b}$ & $8.03^{C}$ & .137 \\
\hline $3 a m$ & $6.01^{a}$ & $7.51^{b}$ & $7.54^{\mathrm{b}}$ & $7.97 \mathrm{C}$ & .111 \\
\hline $7 \mathrm{am}$ & $6.14^{\mathrm{a}}$ & $7.26^{b}$ & $7.32^{b}$ & $7.93 c$ & .085 \\
\hline
\end{tabular}


$\mathrm{NaHCO} 3$ due to lack of $\mathrm{NaCl}$ capacity of renal tubule, therefore increasing urine $\mathrm{pH}$.

Urinary Chloride Excretion

The anion chloride was used to alter the DCAB in diets $L$ and ML. Diet $\mathrm{L}$ was supplemented with . $40 \%$ ammonium chloride and .308 calcium chloride and diet ML was supplemented with .308 calcium chloride. The addition of ammonium chloride and calcium chloride resulted in a lowered DCAB of +10 and +95 for diets $L$ and $M L$ respectively. The effect of DCAB on urinary chloride excretion is shown in Table IV. The decrease in $D C A B$ resulted in increased $(p<.05)$ urinary excretions of chloride in both diet $\mathrm{L}(69.13 \mathrm{~g} / \mathrm{d})$ and $\mathrm{diet}$ ML $(62.76 \mathrm{~g} / \mathrm{d})$ as compared to diet $\mathrm{MH}(34.79 \mathrm{~g} / \mathrm{d})$ and diet $\mathrm{H}$ $(36.12 \mathrm{~g} / \mathrm{d})$. This agrees with data reported by Topliff et al. 1989, Wall et al. 1992 and Baker et al. 1993 which demonstrated an increase in daily urinary excretion of chloride in horses consuming a lower DCAB.

Other data reported by Wall et al. 1993 displayed that decreasing $D C A B$ by increasing dietary chloride caused an increase in the chloride balance in anaerobically exercised horses depending on the level of chloride lost in sweat. Furthermore, this increased chloride balance had marked effect on blood and urine $\mathrm{pH}$ along with calcium, phosphorus, magnesium, and sodium balance in the anaerobically exercised horse. 
Urinary Calcium Excretion

The effect of $D C A B$ on calcium excretion in the urine is shown in Table V. The calcium concentration for all diets was formulated to be equivalent amounts in each treatment. Horses in this trial displayed higher $(p<.05)$ urinary calcium concentrations when consuming diet $\mathrm{L}(44.37 \mathrm{~g} / \mathrm{d})$ and diet ML $(47.24 \mathrm{~g} / \mathrm{d})$ versus those consuming diet $\mathrm{MH}(31.56$ $\mathrm{g} / \mathrm{d})$ and $\operatorname{diet} \mathrm{H}(25.05 \mathrm{~g} / \mathrm{d})$. This concurs with data demonstrating increased urinary calcium excretion with decreased DCAB in horses (Topliff et al., 1989; Wall et al., 1992; and Baker et al., 1993), dairy cattle (Tucker et al., 1988) and rabbits (Thacker, 1959).

The effects of $\mathrm{DCAB}$ on intestinal absorption are not consistent with the other macro minerals. Wall et al. 1993 reported fecal calcium excretion to be higher $(p<.05)$ for horses consuming diet $\mathrm{H}(21.01 \mathrm{~g} / \mathrm{d})$ versus diet $\mathrm{ML}(15.66$ $\mathrm{g} / \mathrm{d})$. This effect is basically opposite of the other minerals reported by these authors, but may be explained by the calcium homeostatic control mechanisms. Wall and others (1993) also reported urinary calcium excretion was lower $(p<.05)$ for horses consuming diet $H(10.33 \mathrm{~g} / \mathrm{d})$ than those consuming diet $\mathrm{L}(21.01 \mathrm{~g} / \mathrm{d})$.

In 1991 Goff et al. showed that parathyroid hormone has been shown to have a more dramatic effect on renal production of 1,25-dihydroxyvitamin $D$ in dairy cows fed highly anionic diets thus increasing intestinal calcium 
absorption. Also these authors reported osteoclastic bone resorption was more responsive to parathyroid hormone as plasma hydroxyproline concentration was higher in those cows fed the low DCAB diet. The increased parathyroid hormone activity may have been due to a decrease in the $\mathrm{pH}$ of the blood caused by consumption of a lower DCAB diet.

The NRC (1989) suggests a calcium requirement for horses of this class to be 1.22 times the Mcal of DE intake/day. Therefore, the horses in this trial would have required approximately 30 grams/day of calcium. Diets in this trial were formulated to exceed the calcium requirement so the horses would not be predisposed to a calcium deficiency. Wall et al. (1993) suggested that due to the tight control of calcium homeostatic mechanisms on intestinal absorption and renal absortion, it would not be feasible to say that the horses in that trial would have been in a negative or marginal calcium balance if calcium levels closer to the requirement had been fed. However, they suggested that as $D C A B$ decreased, calcium balance also decreased, predisposing animals consuming a low DCAB to negative balance. When prolonged, this condition could lead to an osteoporotic weakening of the skeletal system as seen in poultry (Hamilton and Thompson, 1980; Mongin, 1980; and Sauveur and Mongin, 1978). 
TABLE IV

EFFECT OF DIETARY CATION-ANION BALANCE ON URINE CHLORIDE EXCRETION (g/day) POST FEEDING IN EXERCISED HORSES

\begin{tabular}{lllllll}
\hline & \multicolumn{5}{c}{ Treatment } \\
\cline { 2 - 6 } Time & L & ML & MH & H & S.E. \\
\hline Intake, g/d & 90.12 & 72.29 & 42.89 & 41.87 & \\
Urine, g/d & $69.13^{\mathrm{a}}$ & $62.76^{\mathrm{a}}$ & $34.79 \mathrm{~b}$ & $36.12^{\mathrm{b}}$ & 5.617 \\
\hline
\end{tabular}

$a, b$ Means in rows with different superscripts differ $(p<.05)$. 
TABLE V

EFFECT OF DIETARY CATION-ANION BALANCE ON URINE

CALCIUM EXCRETION (g/day) POST FEEDING

IN EXERCISED HORSES

\begin{tabular}{lllllll}
\hline & \multicolumn{5}{c}{ Treatment } \\
\cline { 2 - 6 } Time & $\mathrm{L}$ & $\mathbf{M}$ & $\mathrm{MH}$ & $\mathrm{H}$ & S.E. \\
\hline Intake, g/d & 49.66 & 52.67 & 52.50 & 51.71 & \\
Urine, g/d & $47.35^{\mathrm{a}}$ & $44.24^{\mathrm{a}}$ & $31.56 \mathrm{ab}$ & $25.06 \mathrm{~b}$ & 5.345 \\
\hline
\end{tabular}

$a, b, c$ Means in rows with different superscripts differ $(p<.05)$. 


\section{Blood Acid-Base Parameters}

Differences between $A$ and $V$ blood for the parameters measured were largely insignificant except pCO2 and p02 indicating that venous blood is representative of central circulation with respect to acid-base status. For blood acid-base parameters $(\mathrm{pH}, \mathrm{HCO} 3, \mathrm{pCO} 2, \mathrm{tCO} 2, \mathrm{pO} 2, \mathrm{BEB}$. BEecf and $\mathrm{SBC}$ ) at rest, data in this trial tended to agree with Baker et al. (1992) in that horses consuming anionic diets tended to be acidotic while horses consuming cationic diets tended to be alkalotic at rest. Also, for blood acid-base parameters post anaerobic work, data in this trial tended to agree with stutz et al. (1992) and Milne (1974) as horses performing anaerobic work experienced an incompletely compensated metabolic acidosis.

\section{$\underline{\text { Blood } \mathrm{pH}}$}

The effect of treatment on arterial blood $\mathrm{pH}$ values pre and post-exercise are shown in Table VI. The effect of treatment on venous blood $\mathrm{pH}$ values pre and post-exercise are shown in Table VII. Arterial blood pH decreased with decreasing $D C A B$ for resting values at times pre-exercise (P) and sixty minutes after exercise (60) and was significantly higher at $\mathrm{P}$ and 60 for horses consuming diets $H$ than for those consuming diets $L, M L$, and $M H$. Horses consuming diet MH also experienced higher blood $\mathrm{pH}$ values than for diets $\mathrm{L}$ 
at those times. Although venous blood $\mathrm{pH}$ showed a linear trend as $D C A B$ increased, there were no significant differences between treatments at time $P$. However, the differences for venous blood $\mathrm{pH}$ at time 60 were similar with arterial differences. There were no consistent significant differences between any of the measured blood gas parameters at times $0,1,2,3,4,5,10$ and 30 after anaerobic exercise. Blood $\mathrm{pH}$ decreases as more carbonic acid is formed from an increase in pCO2. To maintain the anion gap, when chloride increases, bicarbonate excretion by the renal tubules decreases, stimulating a metabolic acidosis. However, sodium and potassium are independently controlled by anti-diuretic hormone and aldosterone respectively. Thus, the addition of either of these cations would increase the $\mathrm{pH}$ of the blood by the generation of bicarbonate.

\section{$\underline{B l o O d ~} \mathrm{HCO} 3$}

The effect of DCAB on arterial blood $\mathrm{HCO} 3$ is shown graphically in Table VIII. The effect of DCAB on venous blood $\mathrm{HCO} 3$ is shown graphically in Table IX. Arterial and venous blood $\mathrm{HCO} 3$ showed similar differences as blood pH at rest (times $\mathrm{P}$ and 60 ). At time $\mathrm{P}$, arterial $\mathrm{HCO} 3$ was significantly lower for treatment $L$ than for $M H$ and $H$. For time 60 , arterial $\mathrm{HCO} 3$ was higher $(\mathrm{p}<.05)$ for treatments $\mathrm{H}$ than for $\mathrm{L}, \mathrm{ML}$ and $\mathrm{MH}$. At times $\mathrm{P}$ and 60 horses consuming 
TABLE VI

THE EFFECT OF DIETARY CATION-ANION BAIANCE ON ARTERIAL BLOOD PH IN THE

ANAEROBICALLY EXERCISED HORSE

\begin{tabular}{cccccc}
\hline & \multicolumn{5}{c}{ Treatment } \\
\cline { 2 - 6 } Time & L & M & MH & H & S.E. \\
\hline P & $7.339^{a}$ & $7.372^{b}$ & $7.399^{b}$ & $7.434^{C}$ & .008 \\
0 & $7.319^{a}$ & $7.312^{a}$ & $7.328^{a}$ & $7.307^{a}$ & .024 \\
1 & $7.319^{a}$ & $7.303^{a}$ & $7.333^{a}$ & $7.311^{a}$ & .020 \\
2 & $7.310^{a}$ & $7.309^{a}$ & $3.337^{a}$ & $7.229^{a}$ & .044 \\
3 & $7.321^{a}$ & $7.298^{a}$ & $7.335^{a}$ & $7.292^{a}$ & .025 \\
4 & $7.313^{a}$ & $7.306^{a}$ & $7.345^{a}$ & $7.313^{a}$ & .027 \\
5 & $7.330^{a}$ & $7.322^{a}$ & $7.342^{a}$ & $7.290^{a}$ & .024 \\
10 & $7.353^{a}$ & $7.350^{a}$ & $7.372^{a}$ & $7.327^{a}$ & .019 \\
30 & $7.385^{a}$ & $7.386^{a}$ & $7.413^{a}$ & $7.398^{a}$ & .011 \\
60 & $7.373^{a}$ & $7.406^{b}$ & $7.408^{b}$ & $7.431^{c}$ & .005 \\
\hline
\end{tabular}

$a, b, c$ Means in rows with different superscripts differ $(\mathrm{p}<.05)$. 
TABLE VII

THE EFFECT OF DIETARY CATION-ANION BALANCE

ON VENOUS BLOOD $\mathrm{PH}$ IN THE

ANAEROBICALLY EXERCISED

HORSE

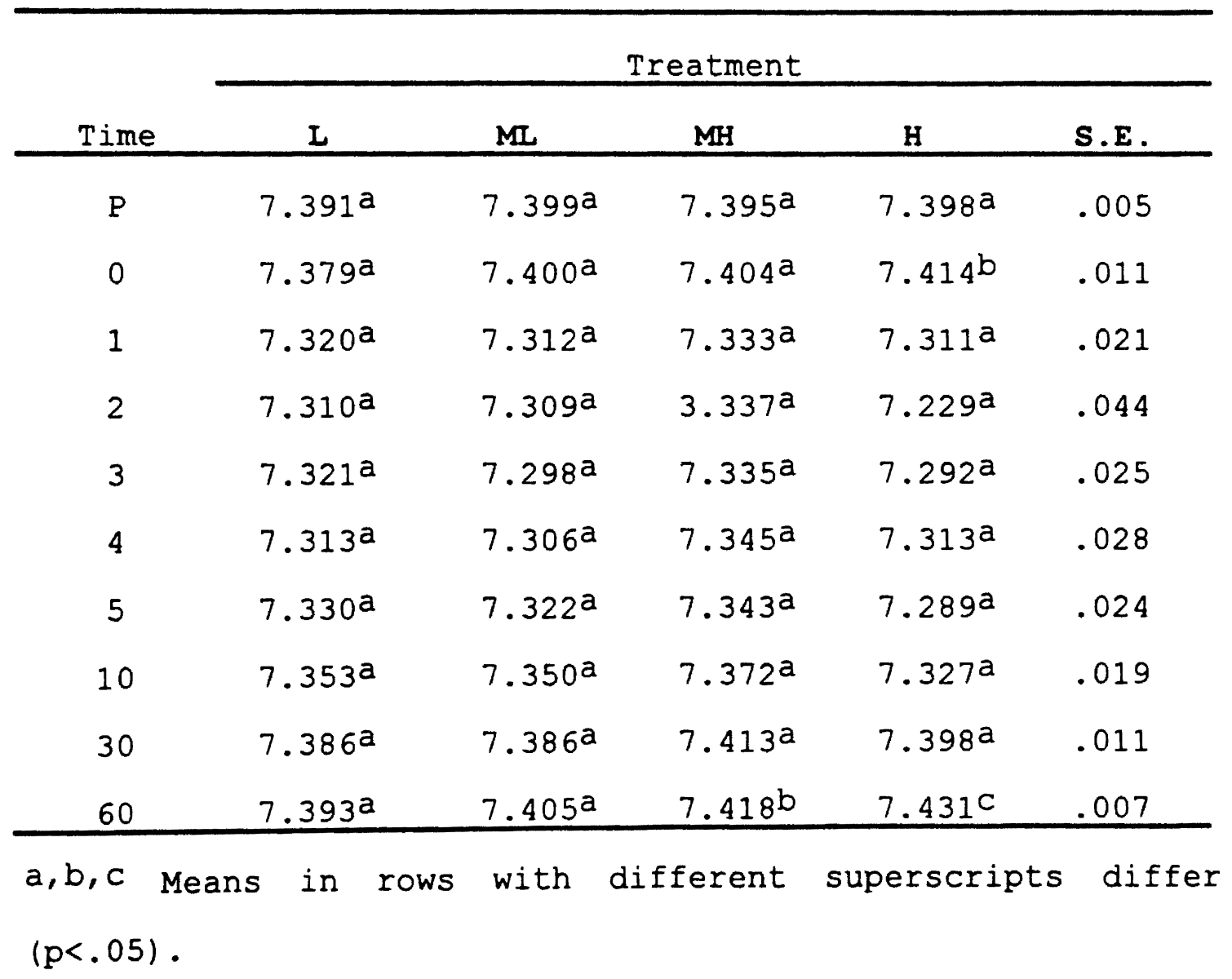


TABLE VIII

EFFECT OF DCAB ON ARTERIAL BLOOD $\mathrm{HCO}_{3}$ (mmOl/l)

IN THE ANAEROBICALLY EXERCISED HORSE.

\begin{tabular}{cccccc}
\hline & \multicolumn{5}{c}{ Treatment } \\
\cline { 2 - 6 } Time & L & M & MH & H & S.E. \\
\hline P & $25.25^{a}$ & $26.28^{a b}$ & $27.65^{b c}$ & $29.13^{c}$ & .477 \\
0 & $19.33^{a}$ & $18.63^{a}$ & $21.08^{a}$ & $20.48^{a}$ & 1.125 \\
1 & $19.48^{a}$ & $18.53^{a}$ & $21.15^{a}$ & $20.50^{a}$ & 1.309 \\
2 & $20.00^{a}$ & $18.68^{a}$ & $21.75^{a}$ & $21.33^{a}$ & 1.426 \\
3 & $20.48^{a}$ & $19.38^{a}$ & $22.53^{a}$ & $21.88^{a}$ & 1.302 \\
4 & $20.33^{a}$ & $19.83^{a}$ & $22.25^{a}$ & $21.88^{a}$ & 1.466 \\
5 & $20.33^{a}$ & $19.85^{a}$ & $21.93^{a}$ & $21.88^{a}$ & 1.439 \\
10 & $22.08^{a}$ & $22.25^{a}$ & $24.53^{a}$ & $22.33^{a}$ & 1.182 \\
30 & $24.30^{a}$ & $25.48^{a b}$ & $26.48^{b}$ & $26.20^{a b}$ & .629 \\
60 & $23.25^{a}$ & $26.53^{b}$ & $27.18^{b}$ & $28.98^{c}$ & .351 \\
\hline
\end{tabular}

$a, b, c$ Means in rows with different superscripts differ $(\mathrm{p}<.05)$ 
TABLE IX

EFFECT OF DCAB ON VENOUS BLOOD HCO3 (mmOl/l)

IN THE ANAEROBICALLY EXERCISED HORSE

\begin{tabular}{cccccc}
\hline & \multicolumn{5}{c}{ Treatment } \\
\cline { 2 - 6 } Time & I & M & MH & H & S.E. \\
\hline P & $27.25^{a}$ & $28.88^{b}$ & $29.75^{b c}$ & $30.68^{c}$ & .441 \\
0 & $19.75^{a}$ & $21.03^{a}$ & $23.98^{b}$ & $22.23^{a b}$ & .892 \\
1 & $20.33^{a}$ & $20.65^{a}$ & $23.23^{a}$ & $21.15^{a}$ & .905 \\
2 & $21.38^{a b}$ & $20.85^{a}$ & $24.00^{b}$ & $21.73^{a b}$ & .833 \\
3 & $21.15^{a}$ & $20.38^{a}$ & $24.50^{b}$ & $21.65^{a}$ & .731 \\
4 & $22.10^{a b}$ & $21.68^{a}$ & $24.83^{b}$ & $22.63^{a b}$ & .833 \\
5 & $21.90^{a}$ & $21.65^{a}$ & $24.60^{a}$ & $22.50^{a}$ & 1.273 \\
10 & $23.58^{a}$ & $23.93^{a}$ & $26.38^{a}$ & $23.20^{a}$ & 1.047 \\
30 & $25.48^{a}$ & $26.55^{a}$ & $28.50^{a}$ & $27.50^{a}$ & .717 \\
60 & $25.13^{a}$ & $28.25^{b}$ & $28.48^{b}$ & $29.55^{b}$ & .541 \\
\hline
\end{tabular}

$a, b, c$ Means in rows with different superscripts differ $(p<.05)$ 
diet $I$ had lower $(p<.05)$ venous blood HCO3 than all other treatments. Furthermore, at time 60, venous $\mathrm{HCO} 3$ was lower for treatment $L$ than for $M L, M H$, and $H$. As with blood $p H$, there were no consistent significant differences for arterial $\mathrm{HCO} 3$ at times 0 through 30 minutes of recovery. When strenuous exercise is performed, there is a marked decrease in bicarbonate, indicating a metabolic acidosis (Milne, 1974). This is due to bicarbonates role in aiding in neutralizing metabolic acids such as lactic acid produced with anaerobic work. When viewing blood $\mathrm{pH}$ and $\mathrm{HCO} 3$ individually, it appears that diet did not effect buffering capacity of the extracellular fluid. But, other data such as lactate concentrations, recovery heart rates and standard exercise test times demonstrate that there was a buffering effect from the highly cationic diet.

\section{Blood $\mathrm{pCO} 2$}

The effect of $D C A B$ on arterial blood $\mathrm{pCO} 2$ is shown in Table $x$. The effect of $D C A B$ on venous blood $p C O 2$ is shown in Table XI. There were no differences $(p<.05)$ between treatments at any time for arterial pCO2. However, horses consuming diet $\mathrm{I}$ had significantly lower venous $\mathrm{pCO} 2$ than those consuming diets $M L, M H$ and $H$ at times $P$ and 60 . As was displayed in arterial and venous $\mathrm{pH}$ and $\mathrm{HCO}$, there were no consistent significant differences between dietary treatments after anaerobic work. There were no differences 
at any time for arterial pCO2 between treatments, but venous pCO2 at times $P$ and 60 for horses consuming diet $L$ had a lower $(\mathrm{p}<.05)$ pCO2 than horses consuming diets $\mathrm{ML}, \mathrm{MH}$, and H. A decrease in blood $\mathrm{pCO2}$, is due to a decrease in bicarbonate in the plasma, which results in an acidemia. Carbon dioxide produced in metabolic processes can combine with water to form $\mathrm{H} 2 \mathrm{CO} 3$. However, this entire reaction is reversed in the lungs when $\mathrm{CO} 2$ is eliminated, or "blown off", by ventilation. In other words, carbon dioxide is a volatile acid.

\section{Blood tCO2}

Similar results were found in arterial and venous tCO2 as compared to $\mathrm{pCO} 2$ at times 0 through 30 minutes post anaerobic work. At times $\mathrm{P}$, arterial tCO2 was different $(p<.05)$ between horses consuming diets $L$ and $M L$ when compared to those consuming diets $\mathrm{MH}$ and $\mathrm{H}$. Also, arterial tCO2 for treatment $L$ was significantly lower than for treatments $\mathrm{ML}, \mathrm{MH}$ and $\mathrm{H}$ at time 60 and as well, treatment $\mathrm{H}$ was significantly higher than treatments $I$ and ML. There were no significant differences between treatments at any time for venous tCO2. The effects of DCAB on arterial and venous blood tCO2 are displayed in Tables XII and XIII respectively. The decrease in the total concentration of carbon dioxide (free and bound) in those horses consuming anionic diets is an indicator of an acidotic state, due 
mostly as with pCO2, to a hyperventilation in response to an acidemia and the increased amounts of $\mathrm{CO} 2$ in the blood.

\section{Blood pO2}

Treatment means for the effects of DCAB on arterial blood p02 are shown in Table XIV. Treatment means for the effects of $D C A B$ on venous blood pO2 are shown in Table XV. There was a reciprocal rise in pO2 as compared to pCO2 due to increased alveolar ventilation. Although there were no consistent significant differences between dietary treatments at $\mathrm{P}, 0,1,2,3,4,5,10,30$ and 60 minutes post exercise, there was a numerical trend for arterial blood po2 to be lower for horses consuming $\operatorname{diet} \mathrm{H}$, particularly at times 30 and 60 . Conversely, venous blood po2 showed a slight numerical trend in horses consuming diet $\mathrm{H}$ to be higher.

\section{Base Excess Blood (BEB), Base Excess}

Extracellular Fluid (BEecf)

Base excess in blood ( $\mathrm{BEb}$ ), is an indicator of the buffering capacity of the blood, usually $\mathrm{HCO}$. The effect of $D C A B$ on $B E b$ of arterial blood is displayed in Table XVI. The effect of $D C A B$ on $B E b$ of venous blood is displayed in Table XVII. Although there were no significant differences in base excess of arterial blood, there was a linear trend 
TABLE X

THE EFFECT OF DIETARY CATION-ANION BALANCE

ON ARTERIAL BLOOD PCO2 (mmHg) IN THE

ANAEROBICALLY EXERCISED

HORSE

\begin{tabular}{cccccc}
\hline & \multicolumn{5}{c}{ Treatment } \\
\cline { 2 - 6 } Time & L & M & MH & H & S.E. \\
\hline P & $42.75^{a}$ & $42.08^{a}$ & $43.25^{a}$ & $44.85^{a}$ & 1.243 \\
0 & $37.10^{a}$ & $36.40^{a}$ & $39.80^{a}$ & $38.13^{a}$ & 1.025 \\
1 & $37.73^{a}$ & $36.93^{a}$ & $39.48^{a}$ & $38.28^{a}$ & 1.242 \\
2 & $39.30^{a b}$ & $36.55^{a}$ & $39.75^{a b}$ & $41.40^{b}$ & 1.277 \\
3 & $40.30^{a}$ & $39.10^{a}$ & $42.63^{a}$ & $41.85^{a}$ & 1.028 \\
4 & $40.60^{a}$ & $39.15^{a}$ & $41.05^{a}$ & $40.20^{a}$ & 1.259 \\
5 & $38.80^{a b}$ & $37.83^{a}$ & $40.65^{a b}$ & $42.35^{b}$ & 1.236 \\
10 & $39.55^{a}$ & $39.73^{a}$ & $41.08^{a}$ & $40.15^{a}$ & .645 \\
30 & $40.18^{a}$ & $42.05^{a}$ & $41.38^{a}$ & $41.08^{a}$ & .975 \\
60 & $40.55^{a}$ & $41.80^{a}$ & $41.70^{a}$ & $42.60^{a}$ & 1.012 \\
\hline
\end{tabular}

$a, b, c$ Means in rows with different superscripts differ $(p<.05)$ 
TABLE XI

THE EFFECT OF DIETARY CATION-ANION BALANCE ON VENOUS BLOOD pCO2 (mmHg) IN THE ANAEROBICALLY EXERCISED

HORSE

\begin{tabular}{cccccc}
\hline & \multicolumn{5}{c}{ Treatment } \\
\cline { 2 - 6 } Time & L & ML & MH & H & S.E. \\
\hline P & $47.10^{a}$ & $49.53^{b}$ & $49.23^{b}$ & $50.93^{b}$ & .536 \\
0 & $38.68^{a}$ & $44.25^{a b}$ & $45.98^{b}$ & $45.38^{b}$ & 1.746 \\
1 & $40.98^{a}$ & $42.18^{a b}$ & $43.70^{b}$ & $40.75^{a}$ & .598 \\
2 & $44.35^{a b}$ & $42.20^{b}$ & $44.98^{a}$ & $45.15^{a}$ & .638 \\
3 & $41.80^{a}$ & $41.50^{a}$ & $44.10^{a b}$ & $44.78^{b}$ & .786 \\
4 & $43.93^{a}$ & $44.13^{a}$ & $45.78^{a}$ & $44.27^{a}$ & .576 \\
5 & $44.40^{a}$ & $44.75^{a c}$ & $46.43^{b}$ & $46.13^{b c}$ & .486 \\
10 & $44.13^{a}$ & $44.93^{a}$ & $45.38^{a}$ & $43.45^{a}$ & 1.071 \\
30 & $43.60^{a}$ & $45.03^{a b}$ & $46.43^{b}$ & $45.78^{a b}$ & .784 \\
60 & $44.58^{a}$ & $46.10^{b}$ & $47.05^{b}$ & $46.95^{b}$ & .449 \\
\hline
\end{tabular}

$a, b, c$ Means in rows with different superscripts differ $(p<.05)$ 
TABLE XII

THE EFFECT OF DIETARY CATION-ANION BALANCE

ON ARTERIAL BLOOD TCO2 (mmHg) IN THE

ANAEROBICALLY EXERCISED

HORSE

\begin{tabular}{cccccc}
\hline & \multicolumn{5}{c}{ Treatment } \\
\cline { 2 - 6 } Time & L & ML & MH & H & S.E. \\
\hline P & $27.19^{a}$ & $27.53^{a b}$ & $29.74^{b c}$ & $31.20^{c}$ & .685 \\
0 & $21.08^{a}$ & $19.73^{a}$ & $22.91^{a}$ & $22.59^{a}$ & 2.113 \\
1 & $20.94^{a}$ & $19.68^{a}$ & $22.68^{a}$ & $22.51^{a}$ & 2.620 \\
2 & $21.59^{a}$ & $19.80^{a}$ & $23.60^{a}$ & $23.56^{a}$ & 2.798 \\
3 & $22.06^{a}$ & $20.63^{a}$ & $24.10^{a}$ & $23.11^{a}$ & 2.606 \\
4 & $21.46^{a}$ & $21.03^{a}$ & $23.74^{a}$ & $23.63^{a}$ & 2.921 \\
5 & $22.18^{a}$ & $21.03^{a}$ & $23.83^{a}$ & $24.28^{a}$ & 2.791 \\
10 & $24.04^{a}$ & $23.50^{a}$ & $26.58^{a}$ & $24.69^{a}$ & 2.162 \\
30 & $25.80^{a}$ & $26.78^{a}$ & $27.81^{a}$ & $27.91^{a}$ & 1.240 \\
60 & $23.99^{a}$ & $27.83^{a}$ & $28.35^{a}$ & $30.54^{a}$ & .693 \\
\hline
\end{tabular}

$a, b, c$ Means in rows with different superscripts differ $(p<.05)$ 
TABLE XIII

THE EFFECT OF DIETARY CATION-ANION BALANCE ON VENOUS BLOOD TCO2 (mmHg) IN THE

ANAEROBICALLY EXERCISED

HORSE

\begin{tabular}{cccccc}
\hline & \multicolumn{5}{c}{ Treatment } \\
\cline { 2 - 6 } Time & L & M & MH & H & S.E. \\
\hline P & $28.30^{a}$ & $30.35^{a}$ & $30.80^{a}$ & $31.50^{a}$ & .530 \\
0 & $18.98^{a}$ & $22.43^{a}$ & $24.58^{a}$ & $21.33^{a}$ & 2.263 \\
1 & $21.45^{a}$ & $21.93^{a}$ & $26.20^{a}$ & $21.43^{a}$ & 3.005 \\
2 & $21.88^{a}$ & $22.15^{a}$ & $25.33^{a}$ & $21.55^{a}$ & 3.879 \\
3 & $22.10^{a}$ & $21.68^{a}$ & $26.45^{a}$ & $22.03^{a}$ & 2.616 \\
4 & $22.88^{a}$ & $23.00^{a}$ & $26.28^{a}$ & $22.50^{a}$ & 2.793 \\
5 & $24.05^{a}$ & $23.00^{a}$ & $27.75^{a}$ & $24.25^{a}$ & 2.919 \\
10 & $25.43^{a}$ & $25.30^{a}$ & $28.78^{a}$ & $24.80^{a}$ & 4.349 \\
30 & $26.83^{a}$ & $27.95^{a}$ & $30.48^{a}$ & $28.80^{a}$ & 3.040 \\
60 & $27.35^{a}$ & $29.65^{a}$ & $31.15^{a}$ & $31.00^{a}$ & 1.803 \\
\hline
\end{tabular}

$a, b, c$ Means in rows with different superscripts differ $(\mathrm{p}<.05)$ 
TABLE XIV

THE EFFECT OF DIETARY CATION-ANION BALANCE ON ARTERIAL BLOOD PO2 (mmHg) IN THE

ANAEROBICALLY EXERCISED

HORSE

\begin{tabular}{cccccc}
\hline & \multicolumn{5}{c}{ Treatment } \\
\cline { 2 - 6 } Time & L & M & MH & H & S.E. \\
\hline P & $152.63^{a}$ & $144.00^{a}$ & $153.38^{a}$ & $137.00^{a}$ & 11.100 \\
0 & $133.38^{a}$ & $127.50^{a}$ & $127.88^{a}$ & $127.25^{a}$ & 10.811 \\
1 & $135.25^{a}$ & $135.50^{a}$ & $138.75^{a}$ & $126.50^{a}$ & 15.629 \\
2 & $119.25^{a}$ & $134.25^{a}$ & $118.13^{a}$ & $128.88^{a}$ & 10.987 \\
3 & $141.88^{a}$ & $138.25^{a}$ & $119.25^{a}$ & $120.63^{a}$ & 4.809 \\
4 & $134.50^{a}$ & $152.50^{a}$ & $139.88^{a}$ & $143.13^{a}$ & 15.060 \\
5 & $129.75^{a}$ & $139.75^{a}$ & $129.38^{a}$ & $125.13^{a}$ & 12.674 \\
10 & $142.25^{a}$ & $156.25^{a}$ & $169.50^{a}$ & $141.50^{a}$ & 11.793 \\
30 & $137.25^{a}$ & $123.50^{a}$ & $140.13^{a}$ & $107.63^{a}$ & 10.869 \\
60 & $133.13^{a}$ & $137.50^{a}$ & $140.13^{a}$ & $109.25^{a}$ & 14.305 \\
\hline
\end{tabular}

$a, b, c$ Means in rows with different superscripts differ $(p<.05)$ 
TABLE XV

THE EFFECT OF DIETARY CATION-ANION BALANCE

ON VENOUS BLOOD PO2 (mmHg) IN THE

ANAEROBICALLY EXERCISED

HORSE

\begin{tabular}{cccccc}
\hline & \multicolumn{5}{c}{ Treatment } \\
\cline { 2 - 6 } Time & I & M & MH & H & S.E. \\
\hline P & $45.50^{a}$ & $45.25^{a}$ & $48.00^{a}$ & $44.75^{a}$ & .707 \\
0 & $68.75^{a}$ & $76.50^{a}$ & $62.75^{a}$ & $76.00^{a}$ & 2.828 \\
1 & $75.00^{a}$ & $63.00^{a}$ & $65.00^{a}$ & $83.50^{a}$ & 7.425 \\
2 & $70.00^{a}$ & $65.50^{a}$ & $63.00^{a}$ & $70.00^{a}$ & 6.010 \\
3 & $68.50^{a}$ & $82.00^{a}$ & $51.50^{a}$ & $60.00^{a}$ & 6.940 \\
4 & $74.00^{a}$ & $59.25^{a}$ & $74.50^{a}$ & $83.25^{a}$ & 5.511 \\
5 & $60.25^{a}$ & $58.50^{a}$ & $58.75^{a}$ & $60.00^{a}$ & 2.828 \\
10 & $62.00^{a}$ & $55.75^{a}$ & $58.50^{a}$ & $67.75^{a}$ & 3.878 \\
30 & $53025^{a}$ & $50.50^{a}$ & $53.75^{a}$ & $61.50^{a}$ & 5.103 \\
60 & $55.25^{a}$ & $49.50^{a}$ & $53.75^{a}$ & $54.50^{a}$ & 4.596 \\
\hline
\end{tabular}

$a, b, c$ Means in rows with different superscripts differ $(p<.05)$ 
TABLE XVI

THE EFFECT OF DIETARY CATION-ANION BALANCE

ON ARTERIAL BLOOD BASE EXCESS (mmOl/L)

IN THE ANAEROBICALLY EXERCISED

HORSE

\begin{tabular}{cccccc}
\hline & \multicolumn{5}{c}{ Treatment } \\
\cline { 2 - 6 } Time & L & ML & MH & H & S.E. \\
\hline P & $0.689^{a}$ & $1.438^{a}$ & $3.900^{a}$ & $5.300^{a}$ & .975 \\
0 & $-5.213^{a}$ & $-7.063^{a}$ & $-1.750^{a}$ & $0.850^{a}$ & 2.075 \\
1 & $-5.250^{a}$ & $-6.700^{a}$ & $-2.050^{a}$ & $0.700^{a}$ & 2.400 \\
2 & $-4.913^{a}$ & $-6.188^{a}$ & $-1.075^{a}$ & $1.400^{a}$ & 2.225 \\
3 & $-4.525^{a}$ & $-6.325^{a}$ & $-0.975^{a}$ & $1.125^{a}$ & 2.500 \\
4 & $-5.213^{a}$ & $-6.438^{a}$ & $-0.375^{a}$ & $3.350^{a}$ & 1.425 \\
5 & $-4.113^{a}$ & $-5.288^{a}$ & $-0.625^{a}$ & $2.550^{a}$ & 1.925 \\
10 & $-1.813^{a}$ & $-2.088^{a}$ & $1.900^{a}$ & $2.375^{a}$ & 1.875 \\
30 & $0.225^{a}$ & $0.975^{a}$ & $3.075^{a}$ & $4.425^{a}$ & .700 \\
60 & $1.450^{a}$ & $1.675^{a}$ & $4.500^{a}$ & $5.925^{a}$ & .800 \\
\hline
\end{tabular}

$a, b, c$ Means in rows with different superscripts differ $(p<.05)$ 
TABLE XVII

THE EFFECT OF DIETARY CATION-ANION BALANCE ON VENOUS BLOOD BASE EXCESS (mmol/L)

IN THE ANAEROBICALLY EXERCISED

HORSE

\begin{tabular}{cccccc}
\hline & \multicolumn{5}{c}{ Treatment } \\
\cline { 2 - 6 } Time & $\mathrm{L}$ & $\mathrm{M}$ & $\mathrm{MH}$ & $\mathrm{H}$ & S.E. \\
\hline $\mathrm{P}$ & $1.606^{\mathrm{a}}$ & $3.175^{\mathrm{a}}$ & $4.075^{\mathrm{b}}$ & $4.319^{\mathrm{b}}$ & .534 \\
0 & $-5.863^{\mathrm{a}}$ & $-5.025^{\mathrm{a}}$ & $-2.500^{\mathrm{a}}$ & $-3.013^{\mathrm{a}}$ & 2.200 \\
1 & $-5.850^{\mathrm{a}}$ & $-5.050^{\mathrm{a}}$ & $-2.875^{\mathrm{a}}$ & $-4.325^{\mathrm{a}}$ & 1.975 \\
2 & $-4.881^{\mathrm{a}}$ & $-4.875^{\mathrm{a}}$ & $-2.775^{\mathrm{a}}$ & $-4.144^{\mathrm{a}}$ & 1.957 \\
3 & $-4.419^{\mathrm{a}}$ & $-5.250^{\mathrm{a}}$ & $-2.025^{\mathrm{a}}$ & $-4.331^{\mathrm{a}}$ & 1.977 \\
4 & $-4.063^{\mathrm{a}}$ & $-4.225^{\mathrm{a}}$ & $-1.775^{\mathrm{a}}$ & $-3.038^{\mathrm{a}}$ & 1.596 \\
5 & $-3.538^{\mathrm{a}}$ & $-4.450^{\mathrm{a}}$ & $-1.725^{\mathrm{a}}$ & $-2.138^{\mathrm{a}}$ & 2.196 \\
10 & $-1.388^{\mathrm{a}}$ & $-1.650^{\mathrm{a}}$ & $0.775^{\mathrm{a}}$ & $-0.688^{\mathrm{a}}$ & 2.183 \\
30 & $0.5556^{\mathrm{a}}$ & $1.450^{\mathrm{a}}$ & $2.925^{\mathrm{a}}$ & $2.844^{\mathrm{a}}$ & 1.295 \\
60 & $0.681^{\mathrm{a}}$ & $3.150^{\mathrm{a}}$ & $3.975^{\mathrm{b}}$ & $4.469^{\mathrm{b}}$ & .548 \\
\hline
\end{tabular}

$a, b, c$ Means in rows with different superscripts differ $(p<.05)$ 
from treatments I to $H$. Furthermore, horses consuming diet $\mathrm{H}$ had numerically higer concentrations of arterial BEb and values were positive at all times. The numerical increase in base excess could indicate that the buffering capacity of the blood was increased due to the consumption of highly cationic diets. This is of particular interest when viewing the positive arterial BEb values of treatment after anaerobic work which indicate that horses consuming diet $\mathrm{H}$ may have recovered more quickly, possibly due to a greater buffering capacity. Conversely, the decrease in base excess in highly anionic diets indicates that the buffering capacity of the blood was lowered. Even though the range of values of $\mathrm{BEb}$ from diets $\mathrm{L}$ to $\mathrm{H}$ was narrower for venous versus arterial, least square means declared horses consuming diet $L$ to have less venous $B E b$ than those consuming diets $\mathrm{MH}$ and $\mathrm{H}$.

The effect of $D C A B$ on arterial blood base excess extracellular fluid (BEecf) is shown in Table XVIII. The effect of $D C A B$ on venous blood BEecf is shown in Table XIX. BEecf is also used as an indicator of the buffering capacity of the blood. Results for BEecf were similar to those seen in BEb. Horses consuming diets $I$ had lower $(p<.05)$ arterial BEecf than those consuming diet $H$ at time $P$ and 60 . Further, horses consuming diet $\mathrm{H}$ had higher $(\mathrm{p}<.05)$ arterial BEecf than those consuming diets $L$ and $M L$ at time 60. Also, venous BEecf was lower $(p<.05)$ for treatment $L$ when compared to all other treatments at time $P$ and treatments $L$ and $H$ 
were significantly different at time 60 . This is a further indication that horses consuming diet $L$ had a lowered buffering capacity and correlates with the metabolic acidosis as shown by blood $\mathrm{pH}$ and $\mathrm{HCO}$.

\section{Blood Lactate Concentration}

Table XX displays the effect of DCAB on blood lactate concentration (IA). Blood LA concentrations were significantly lower for horses consuming diet $L$ at times $P$ and 60 than for diets $\mathrm{ML}, \mathrm{MH}$ and $\mathrm{H}$, and were numerically highest at all times for horses consuming diet $\mathrm{H}$. During anaerobic glycolysis, lactate and hydrogen ions are released in stoichiometric equal amounts. When hydrogen ions leave the muscle and enter the blood they are sequestered by both bicarbonate and non-bicarbonate buffering systems. During the standard exercise test (SET), mass over distance was held constant since all horses were worked the same distance with the same rider and at a constant heart between 200 and 210 beats per minute throughout the sprint in an effort to standardize work intensity. Therefore, horses consuming diet $\mathrm{H}$ may have had higher lactate clearance rates due to increased $\mathrm{NaHCO} 3$ concentrations in the blood, facilitating the flow of hydrogen ions out of the cells. This agrees with Lawrence et al. (1987). This could account for the higher blood IA concentrations in the blood in horses 
TABLE XVIII

THE EFFECT OF DIETARY CATION-ANION BALANCE ON ARTERIAL BLOOD BASE EXCESS EXTRACELLULAR

FLUID (mmOl/L) IN THE ANAEROBICALLY

EXERCISED HORSE

\begin{tabular}{cccccc}
\hline & \multicolumn{5}{c}{ Treatment } \\
\cline { 2 - 6 } Time & L & M & MH & H & S.E. \\
\hline$P$ & $-0.175^{a}$ & $1.275^{a}$ & $2.250^{a}$ & $3.467^{b}$ & .708 \\
0 & $-6.925^{a}$ & $-7.050^{a}$ & $-5.375^{a}$ & $-5.483^{a}$ & 1.673 \\
1 & $-6.350^{a}$ & $-7.025^{a}$ & $-5.275^{a}$ & $-5.000^{a}$ & 1.682 \\
2 & $-6.350^{a}$ & $-6.550^{a}$ & $-4.450^{a}$ & $-4.083^{a}$ & 1.649 \\
3 & $-5.675^{a}$ & $-6.350^{a}$ & $-3.775^{a}$ & $-4.083^{a}$ & 1.612 \\
4 & $-5.425^{a}$ & $-5.800^{a}$ & $-3.650^{a}$ & $-2.442^{a}$ & 1.784 \\
5 & $-5.525^{a}$ & $-5.575^{a}$ & $-3.750^{a}$ & $-3.200^{a}$ & 1.681 \\
10 & $-3.825^{a}$ & $-3.525^{a}$ & $-0.275^{a}$ & $-2.975^{a}$ & 1.612 \\
30 & $-1.075^{a}$ & $0.275^{a}$ & $2.025^{a}$ & $1.492^{a}$ & .898 \\
60 & $0.375^{a}$ & $1.650^{a}$ & $2.925^{b}$ & $4.167^{c}$ & .594 \\
\hline
\end{tabular}

$a, b, c$ Means in rows with different superscripts differ $(p<.05)$ 
TABLE XIX

THE EFFECT OF DIETARY CATION-ANION BALANCE

ON VENOUS BLOOD BASE EXCESS EXTRACELLULAR

FLUID (mmOl/L) IN THE ANAEROBICALLY

EXERCISED HORSE

\begin{tabular}{cccccc}
\hline & \multicolumn{5}{c}{ Treatment } \\
\cline { 2 - 6 } Time & $\mathrm{L}$ & $\mathrm{M}$ & $\mathrm{MH}$ & $\mathrm{H}$ & S.E. \\
\hline $\mathrm{P}$ & $1.875^{\mathrm{a}}$ & $4.743^{\mathrm{b}}$ & $4.413^{\mathrm{b}}$ & $5.294^{\mathrm{b}}$ & .253 \\
0 & $-5.475^{\mathrm{a}}$ & $-1.813^{\mathrm{a}}$ & $-4.150^{\mathrm{a}}$ & $-0.863^{\mathrm{a}}$ & 1.389 \\
1 & $-5.325^{\mathrm{a}}$ & $-1.281^{\mathrm{a}}$ & $-4.038^{\mathrm{a}}$ & $-2.631^{\mathrm{a}}$ & 1.354 \\
2 & $-4.275^{\mathrm{a}}$ & $-1.556^{\mathrm{a}}$ & $-4.038^{\mathrm{a}}$ & $-2.256^{\mathrm{a}}$ & 1.641 \\
3 & $-4.100^{\mathrm{a}}$ & $-1.569^{\mathrm{a}}$ & $-3.588^{\mathrm{a}}$ & $-2.069^{\mathrm{a}}$ & 1.091 \\
4 & $-3.500^{\mathrm{a}}$ & $-0.781^{\mathrm{a}}$ & $-3.563^{\mathrm{a}}$ & $-1.231^{\mathrm{a}}$ & 1.251 \\
5 & $-3.600^{\mathrm{a}}$ & $1.144^{\mathrm{a}}$ & $-3.413^{\mathrm{a}}$ & $-0.606^{\mathrm{a}}$ & 1.704 \\
10 & $-1.925^{\mathrm{a}}$ & $2.475^{\mathrm{a}}$ & $-1.925^{\mathrm{a}}$ & $-0.075^{\mathrm{a}}$ & 1.426 \\
30 & $0.475^{\mathrm{a}}$ & $4.231^{\mathrm{a}}$ & $2.387^{\mathrm{a}}$ & $4.131^{\mathrm{a}}$ & 1.192 \\
60 & $0.875^{\mathrm{a}}$ & $5.169^{\mathrm{a}}$ & $4.663^{\mathrm{a}}$ & $5.719^{\mathrm{b}}$ & .803 \\
\hline
\end{tabular}

$a, b, c$ Means in rows with different superscripts differ $(p<.05)$ 
TABLE XX

THE EFFECT OF DIETARY CATION-ANION BALANCE ON BLOOD LACTATE CONCENTRATIONS (mg/dL) IN

THE ANAEROBICALLY EXERCISED HORSE

\begin{tabular}{cccccc}
\hline & \multicolumn{5}{c}{ Treatment } \\
\cline { 2 - 6 } Time & $\mathrm{L}$ & $\mathrm{ML}$ & $\mathrm{MH}$ & $\mathrm{H}$ & S.E. \\
\hline $\mathrm{P}$ & $8.27^{\mathrm{a}}$ & $10.09^{\mathrm{b}}$ & $10.50^{\mathrm{b}}$ & $10.70^{\mathrm{b}}$ & .368 \\
0 & $41.06^{\mathrm{a}}$ & $67.81^{\mathrm{bc}}$ & $54.73^{\mathrm{ab}}$ & $84.24^{\mathrm{C}}$ & 5.838 \\
1 & $44.26^{\mathrm{a}}$ & $67.82^{\mathrm{bc}}$ & $54.73^{\mathrm{ab}}$ & $84.24 \mathrm{c}$ & 6.075 \\
2 & $44.38^{\mathrm{a}}$ & $66.56^{\mathrm{bc}}$ & $54.30^{\mathrm{ab}}$ & $78.26 \mathrm{C}$ & 5.337 \\
3 & $40.61^{\mathrm{a}}$ & $64.64^{\mathrm{bc}}$ & $52.61^{\mathrm{ab}}$ & $80.47 \mathrm{C}$ & 5.700 \\
4 & $40.34^{\mathrm{a}}$ & $62.54^{\mathrm{bc}}$ & $49.61^{\mathrm{ab}}$ & $80.96 \mathrm{c}$ & 6.405 \\
5 & $39.36^{\mathrm{a}}$ & $57.65^{\mathrm{bc}}$ & $49.08^{\mathrm{ab}}$ & $75.57 \mathrm{c}$ & 6.031 \\
10 & $26.01^{\mathrm{a}}$ & $45.91^{\mathrm{bc}}$ & $33.05^{\mathrm{ab}}$ & $62.07 \mathrm{c}$ & 5.845 \\
30 & $13.86^{\mathrm{a}}$ & $21.75^{\mathrm{bc}}$ & $16.89^{\mathrm{ab}}$ & $35.46^{\mathrm{c}}$ & 3.205 \\
60 & $9.325^{\mathrm{a}}$ & $13.61^{\mathrm{bc}}$ & $12.11^{\mathrm{ab}}$ & $15.52^{\mathrm{c}}$ & 1.043 \\
\hline
\end{tabular}

$a, b, c$ Means in rows with different superscripts differ $(p<.05)$ 
TABLE XXI

THE EFFECT OF DIETARY CATION-ANION BALANCE ON RECOVERY HEART RATES IN THE ANAEROBICALLY

EXERCISED HORSE

\begin{tabular}{cccccc}
\hline & \multicolumn{5}{c}{ Treatment } \\
\cline { 2 - 6 } Time & L & ML & MH & H & S.E. \\
\hline P & $41.25^{\mathrm{a}}$ & $42.50^{\mathrm{a}}$ & $41.25^{\mathrm{a}}$ & $45.00^{\mathrm{a}}$ & 1.299 \\
0 & $195.00^{\mathrm{a}}$ & $187.75^{\mathrm{ab}}$ & $184.50^{\mathrm{b}}$ & $181.50^{\mathrm{b}}$ & 2.548 \\
1 & $116.75^{\mathrm{a}}$ & $111.00^{\mathrm{a}}$ & $107.75^{\mathrm{a}}$ & $108.75^{\mathrm{a}}$ & 2.886 \\
2 & $96.00^{\mathrm{ab}}$ & $98.50^{\mathrm{b}}$ & $98.50^{\mathrm{b}}$ & $91.50^{\mathrm{a}}$ & 1.843 \\
3 & $91.50^{\mathrm{a}}$ & $91.00^{\mathrm{a}}$ & $84.75^{\mathrm{b}}$ & $78.75^{\mathrm{C}}$ & 1.581 \\
4 & $85.00^{\mathrm{a}}$ & $86.75^{\mathrm{a}}$ & $80.75^{\mathrm{ab}}$ & $75.00^{\mathrm{b}}$ & 2.287 \\
5 & $83.00^{\mathrm{a}}$ & $83.50^{\mathrm{a}}$ & $77.25^{\mathrm{a}}$ & $67.25^{\mathrm{b}}$ & 2.784 \\
10 & $74.25^{\mathrm{a}}$ & $74.50^{\mathrm{a}}$ & $66.50^{\mathrm{b}}$ & $62.00^{\mathrm{b}}$ & 1.612 \\
\hline 30 & $61.50^{\mathrm{a}}$ & $62.00^{\mathrm{a}}$ & $53.00^{\mathrm{b}}$ & $51.00^{\mathrm{b}}$ & 1.963 \\
60 & $43.25^{\mathrm{a}}$ & $44.25^{\mathrm{a}}$ & $41.25^{\mathrm{a}}$ & $42.25^{\mathrm{a}}$ & 1.607 \\
\hline
\end{tabular}

$a, b, c$ Means in rows with different superscripts differ $(p<.05)$ 
TABLE XXII

THE EFFECT OF DIETARY CATION-ANION BALANCE

ON STANDARD EXERCISE TEST TIMES IN THE

ANAEROBICALLY EXERCISED HORSE

\begin{tabular}{lllll}
\hline \hline Treatment & $\mathrm{L}$ & $\mathrm{ML}$ & $\mathrm{MH}$ & $\mathrm{H}$ \\
\hline $\begin{array}{l}\text { SET Times } \\
(\text { min:sec) }\end{array}$ & $2: 55^{\mathrm{a}}$ & $2: 37 \mathrm{ab}$ & $2: 31 \mathrm{bc}$ & $2: 26 \mathrm{C}$ \\
& & & & \\
\hline
\end{tabular}

abcMeans in rows with different superscripts differ $(p<.10)$. 
consuming diet $\mathrm{H}$. The higher levels of blood LA concentrations and unchanged blood $\mathrm{pH}$ after anaerobic work indicates a buffering effect from diet $H$ in this trial.

\section{Heart Rates and SET TIMES}

The effect of $D C A B$ on recovery heart rates is shown in Table XXI. Recovery heart rates were significantly lower at times 3,4,5,10 and 30 REC for horses consuming diet $H$. This further suggests a buffering effect in horses consuming diet H. In addition, least squares means for SET times were significantly shorter for horses consuming diet $\mathrm{H}$ as compared to diet $\mathrm{L}$. Standard exercise test times are shown in Table XXII. Faster SET times worked at a constant heart rate indicate that horses consuming diet $H$ also had increased performance levels. This is in agreement with Lawrence et al. (1990) who reported faster times and a greater capability of the blood bicarbonate buffering system to promote lactic acid efflux from the muscle due to $\mathrm{NaHCO}_{3}$ ingestion 2.5 hours prior to racing. 
CHAPTER V

SUMMARY AND CONCLUSIONS

From these data we conclude that the ratio of cations to anions in the diet influences acid-base balance, and that horses consuming diets with a low DCAB may experience a nutritionally induced metabolic acidosis. Moreover, there appeared to be a buffering effect of the highly cationic diet post exercise, which resulted in improved performance and faster recovery of heart rate even though there was an increase in blood lactate concentrations. This trial also demonstrates that urinary calcium excretion is increased in horses consuming diets with a low DCAB, and this excretion may possibly cause an increase in the risk of bone disorders. This could have a significant impact on young growing horses, and on horses competing in events that create bone trauma.

The levels at which $D C A B$ are fed in the diet still need to be quantified, and the classes of horses it effects needs to be determined. An increase in milk production in the mare may be possible, as it has been demonstrated in dairy cattle. Feeding a higher $D C A B$ has been determined to play a role in the reduction of tibial dyschondroplasia in growing 
chicks. It is possible that developmental orthopedic disease may also be reduced by closely monitoring the DCAB of young growing horses, as well as monitoring other nutritional ratios such as calcium : phosphorous and protein : calorie.

These data demonstrate that anaerobic performance may be enhanced through the feeding of highly cationic diets when exercise is performed within 4 hours post feeding. Further research is needed to determine the optimum level of DCAB for horses performing anaerobic work, and research to determine the effects of $D C A B$ on young growing horses. 


\section{LITERATURE CITED}

Austic, R.E. 1984. Excess dietary chloride depressed eggshell quality. Poultry sci. 63:1773.

Baker, L.A., D.R. Topliff, D.W. Freeman, R.G. Teeter and J.E. Breazile. 1992. Effect of dietary cation-anion balance on acid-base status in horses. J. Equine Vet. Sci. $12: 160$.

Beighle,D.E, W.B. Tucker and R.W. Hemken. 1990.

Interactions of dietary cation-anion balance and phosphorus effects on blood, bone and faecal phosphorus concentrations in dairy calves. Tydskr. S. Afr. Vet. Ver. $61:(1): 5-8$.

Block, E. 1984. Manipulating dietary anions and cations for prepartum dairy cows to reduce the incidence of milk fever. J. Dairy Sci. 67:2939.

Church, D.C. and J.P. Fontenot. 1979. The macro (major) minerals. In: D.C. Church (Ed) Digestive Physiology and Nutrition of Ruminants. pp82-83. O\&B Books, Inc., Corvallis, OR.

Cohen, I., S. Hurwitz and A. Bar. 1972. Acid-base balance and sodium to chloride ratio in diets of laying hens. AJ. Nutr. 102:1-8. 
Cohen, I. and S. Hurwitz. 1974. The response of blood ionic constituents and acid-base balance to dietary sodium, potassium and chloride in laying fowls. Poultry Sci. $\quad 53: 378-383$.

Frank, F.R. and R.E. Beger. 1965. The effect of carbon dioxide inhalation and sodium bicarbonate ingestion on egg shell deposition. Poultry Sci. 44:1604.

Goff, J.P., R.L. Horst, F.J. Mueller, J.K. Miller, G.A. Kiess and H. H. Dowlen. 1991. Addition of chloride to a prepartal diet high in cations increases 1,25 dihydroxyvitamin $D$ response to hypocalcemia preventing milk fever. J. Dairy Sci. 74:3863-3871.

Golz, D.I. and T.D. Crenshaw. 1990. Interrelationships of dietary sodium, potassium and chloride on growth in young swine. J. Anim. Sci. 68:2736.

Hamilton, R.M.G., and B.K. Thompson. 1980. Effects of sodium plus potassium to chloride ratio in practical-type diets on blood gas levels in three strains of white Leghorn and the relationship between acid-base balance and egg shell strength. Poultry Sci. 59:1294-1303.

Honeyfield, D.C., J.A. Froseth and R.J. Barke. 1985. Dietary sodium and chloride levels for growing-finishing pigs. J. Anim. Sci. 60:691.

Hunt, J.R. and J.R. Aitken. 1962. The effect of ammonium and chloride ions in the diet of hens on egg shell quality. Poultry sci. 41:434-438.

Johnson, R.J., and H. Karunajeewa. 1985. The effects of dietary minerals and electrolytes on the growth and physiology of the young chick. J. Nutr. 115:1680-1690. 
Kellaway, R.C., D.J. Thompson, D.E. Beever, and D.F. Osbourn. 1977. Effects of $\mathrm{NaCl}$ and $\mathrm{NaHCO} 3$ on food intake, growth rate and acid-base balance in calves. $J$. Agric. Sci. (Camb.) $88: 1$

Kelso, T.B., D.R. Hodgson, E.H. Witt, W.M. Bayly, B.D. Grant and P.D. Gollnick. 1987. Bicarbonate administration and muscle metabolism during high intensity exercise. In: J.R. Gillespie nd N.E. Robinson (Eds.) Equine Exercise Physiology II. pp464-475. ICEEP Publications, Davis, $C A$.

Lawrence, L.M., P.A. Miller, P.J. Bechtel, R.A. Kane, E.V. Kurcz, and J.S. Smith. 1987. The effect of sodium bicarbonate ingestion on blood parameters in exercising horses. In: J.R. Gillespie nd N.E. Robinson (Eds.) Equine Exercise Physiology II. pp464-475. ICEEP Publications, Davis, CA.

Lawrence, L.M., K. Kline, P. Miller-Graber, A. Siegel, E. Kurcz, M. Fisher, and K. Bump. 1990. Effect of sodium bicarbonate on racing standardbreds. J. Anim. Sci. $68: 673$.

Leibholz, J.M., J.T. McCall, V.W. Hays and V.C. Speer. 1966. Potassium, protein and basic amino acid relationship in swine. J. Anim. Sci. 25:37.

Madubuike, F.N., C.C. Calvert and R.E. Austic. 1980. Lysine-cation interrelationships in the pig. J. Anim. Sci. 51 (Suppl. 1):210. 
Marlin, D.J., R.C. Harris, J.C. Harman, and D.H. Snow. 1987. Influence of post-exercise activity on rates of muscle and blood lactate disappearance in the Thoroughbred horse. In: J.R. Gillespie nd N.E. Robinson (Eds.) Equine Exercise Physiology II. pp464-475. ICEEP Publications, Davis, CA.

Melliere, A.L., and R.M. Forbes. 1966. Effect of altering the dietary cation-anion ratio on food consumption and growth of young chicks. J. Nutr. 90:310.

Miller, P.A., and I.M. Lawrence. 1987. The effect of submaximal treadmill training on heart rate, lactate and ammonia in Quarter Horses. In: J.R. Gillespie nd N.E. Robinson (Eds.) Equine Exercise Physiology II. pp464475. ICEEP Publications, Davis, CA.

Milne, D.W. 1974. Blood gases, acid-base balance and electrolyte and enzyme changes in exercising horses. J. S. Afr. Vet. Assoc. 45(4):345-354.

Milne, D.W., R.T. Skarda, A.A. Gabel, L.G. Smith and K. Ault. 1976. Effects of training on biochemical values in Standardbred horses. Am. J. Vet, Res. 37:285-290.

Mongin, P. and B. Sauveur. 1977. Interrelationship between mineral nutrition, acid-base balance, growth and cartilage abnormalities. In: Boorman, K.N. and Wilson B., (Eds,) Growth and Poultry Meat Production. Br. Poultry Sci. Ltd., London, U.K. 1977:235-47.

Mongin, P. 1968. Role of acid-base balance in the physiology of egg shell formation. World's Poultry sci. J. $24: 200$. 
Mongin, P. 1980. Electrolytes in nutrition: a review of basic principles and practical application in poultry and swine. In: Proc. 3rd Annu. Int. Miner. Conf., Orlando, FL. pp:200-229.

Morgen, A. and C. Beger. 1915. Uber den schaddechen, auf eine sauerevergiftung zur uckzufuhren den einfluss winer ausschliess lichen haferfutterung. Z. Physiol. Shem. 94-324.

Neshiem, M.C., R.M. Leach, T.R. Zeigler, and J.A. Seratin. 1964. Interrelationships between dietary levels of sodium, chloride and potassium. J. Nutr. 84:361-66.

NRC. 1989. Nutrient Requirements of Domestic Animals. No. 14. Nutrient Requirements of Horses. Fifth Revised Ed. National Academy of Sciences-National Research Council. Washington, DC.

Oetzal, G.R. 1991. Meta-analysis of nutritional risk factors for milk fever in dairy cattle. J. Dairy Sci. 74 (Suppl, 1):291, (Abstr.).

Patience, J.F., R.E. Austic and R.D. Boyd. 1987. Effect of dietary electrolyte balance on growth and acid-base status in swine. J. Anim. Sci. 64:457.

SAS Institute Inc. 1985. SAS User's Guide: Statistics, Version 5 Edition. Cary NC:SAS Institute Inc.

Sauveur, B., and P. Mongin 1978. Tibial dyschondroplasia, a cartilage abnormality in poultry. Ann. Biol. Anim. Bioch. Biophys. 18:87-98. 
Snow, D.H., R.C. Harris and S.P. Gash. 1985. Metabolic response of equine muscle to intermittent maximal exercise. J. Appl. Phys. 58(5):1689-1697.

Spears, J.W., J.C. Burns and P.A. Hatch. 1985. Sulfur fertilization of cool season grasses and effect on utilization of minerals, nitrogen, and fiber by steers. J. Dairy Sci. $68: 347$.

Stutz, W.A., D.R. Topliff, D.W. Freeman, W.B. Tucker and J.E. Breazile. 1992. Effects of dietary cation-anion balance on blood parameters in exercising horses. J. Equine Vet. Sci. 12:160.

Thacker, E.J. 1959. Effect of a physiological cation-anion imbalance on the growth and mineral nutrition of rabbits. J. Nutr. $69: 28$.

Thornton, J., B. Essen-Gustavsson, A. Lindholm, D. McMiken and S. Persson. 1983. Effects of training and detraining on oxygen uptake, cardiac output, blood gas tension, $\mathrm{pH}$ and lactate concentrations during and after exercise in the horse. In: Equine Exercise Physiology. Snow, D.H., S. Persson and R.J. Rose (Eds.) Granta Editions, Cambridge, pp470-486.

Topliff, D.R., M.A. Kennerly, D.W. Freeman, R.G. Teeter and D.G. Wagner. 1989. Changes in urinary and serum calcium and chloride concentrations in exercising horses fed varying cation-anion balances. Proc. Eleventh Equine Nutr. and Physio. Symp. Stillwater, OK. 1.

Tucker, W.B., G.A. Harrison and R.W. Hemken. 1988. Influence of dietary cation-anion balance on milk, blood, urine and rumen fluid in lactating dairy cattle. J. Dairy Sci. $71: 346$. 
Tucker, W.B., J.F. Hogue, D.F. Waterman, T.S. Swenson, Z. Xin, R.W. Hemken, J.A. Jackson, G.D. Adams and L.J. Spicer. 1991. Role of sulphur and chloride in the dietary cation-anion balance equation for lactating dairy cattle. J. Anim. Sci. 69:1205.

Tucker, W.B., J.A. Jackson, D.M. Hopkins, and J.F. Hogue. 1991. Influence of dietary sodium bicarbonate on the potassium metabolism of growing dairy calves. J. Dairy sci. $74: 1401$.

Wall, D.L., D.R. Topliff, D.W. Freeman, D.G. Wagner and J.E. Breazile. 1992. Effects of dietary cation-anion balance on urinary mineral excretion in exercised horses. J. Equine Vet. Sci. 12:168.

Wall, D.L, D.R. Topliff, D.W. Freeman, D.G. Wagner and J.E. Breazile. 1993. The effect of dietary cation-anion balance on mineral balance in the anaerobically exercised horse. Proc. Thirteenth Equine Nutr. and Physio. Symp. Gainesville, FL. 50.

Webb, S.P., G.D. Potter, J.W. Evans and L.W. Grene. 1988. Physiological responses of cutting horses to exercise testing and to training. J. Equine Vet. Sci. 8(3):261265.

Williamson, H.M. 1974. Normal and abnormal electrolyte levels in the racing horse and their effect on performance. J. S. Afr. Vet. Ass. $45(4): 335-340$.

Yen, J.T., W.G. Pond and R.L. Prior. 1981. Calcium chloride as a regulator of feed intake and weight gain in pigs. J. Anim. Sci. 52:778. 


\author{
Vita \\ Joseph Charles Popplewell \\ Candidate for the Degree of \\ Master of Science
}

\title{
Thesis: THE EFFECTS OF DIETARY CATION-ANION BAIANCE ON ACID-BASE bAIANCE AND
}

BLOOD PARAMETERS IN ANAERCBICALLY EXXECISED HORSES

Major Field: Animal Science

Biographical:

Personal Data: Bom in Ponca City, Oklahoma, March 8, 1965, the son of Charles and Adel Popplewell.

Ecucation: Grachated from Ponca City High School, Ponca City, Oklahoma, in May, 1983; received Associates of Applied Science Degree in Agribusiness from Northem Oklahoma College in Tonkawa, Oklhahoma in May, 1985; received Bachelor of Science Degree in Animal Science from Oklahoma State University in Stillwater, Oklahoma in May, 1988; completed requirements for the Master of Science degree at Oklahoma State University in December, 1993.

Professional Organizations: Student member of Equine Nutrition \& Physiology Society and American Society of Animal Science.

Professional Experience: Management Trainee, Pig Improvement Campany, Hennessey, Oklahoma, Feb. 1993 to present; Assistant Manager, Bowlan Farms, Tecumseh, Oklahama, Aug. 1990 to Aug 1991; Manager, Gina's Stables, Eamond, Oklahoma, Aug 1988 to Aug 1990; Sale's Manager, Roy Browning Ranches, Ada, Oklahoma, April to Aug. 1988 